USGS Professional Paper 1703-Ground-Water Recharge in the Arid and Semiarid Southwestern United StatesChapter E

\title{
Focused Ground-Water Recharge in the Amargosa Desert Basin
}

\author{
By David A. Stonestrom, David E. Prudic, Michelle A. Walvoord, Jared D. Abraham, Amy E. Stewart-Deaker'1, \\ Patrick A. Glancy, Jim Constantz, Randell J. Laczniak, and Brian J. Andraski
}

\section{Abstract}

The Amargosa River is an approximately 300-kilometer-long regional drainage connecting the northern highlands on the Nevada Test Site in Nye County, Nev., to the floor of Death Valley in Inyo County, Calif. Streamflow analysis indicates that the Amargosa Desert portion of the river is dry more than 98 percent of the time. Infiltration losses during ephemeral flows of the Amargosa River and Fortymile Wash provide the main sources of ground-water recharge on the desert-basin floor. The primary use of ground water is for irrigated agriculture. The current study examined ground-water recharge from ephemeral flows in the Amargosa River by using streamflow data and environmental tracers. The USGS streamflow-gaging station at Beatty, Nev., provided highfrequency data on base flow and storm runoff entering the basin during water years 1998-2001. Discharge into the basin during the four-year period totaled 3.03 million cubic meters, three quarters of which was base flow. Streambed temperature anomalies indicated the distribution of ephemeral flows and infiltration losses within the basin. Major storms that produced regional flow during the four-year period occurred in February 1998, during a strong El Niño that more than doubled annual precipitation, and in July 1999. The study also quantified recharge beneath undisturbed native vegetation and irrigation return flow beneath irrigated fields. Vertical profiles of water potential and environmental tracers in the unsaturated zone provided estimates of recharge beneath the river channel (0.04-0.09 meter per year) and irrigated fields (0.1-0.5 meter per year). Chloride mass-balance estimates indicate that 12-15 percent of channel infiltration becomes ground-water recharge, together with 9-22 percent of infiltrated irrigation. Profiles of potential and chloride beneath the dominant desert-shrub vegetation suggest that ground-water recharge has been negligible throughout most of the basin since at least the early Holocene. Surface-based electrical-resistivity imaging provided areal extension of borehole information from sampled profiles. These images indicate narrowly focused recharge beneath the Amargosa River channel, flanked by large tracts of rechargefree basin floor.

\footnotetext{
${ }^{1}$ Present address Berkeley, California (amystew@gmail.com).
}

\section{Introduction and Setting}

The Amargosa Desert Basin contains a large quantity of high quality ground water (Walker and Eakin, 1963; Claassen, 1985; Kilroy, 1991). Beneficial uses of ground water include sustenance of wildlife at discharge points within Ash Meadows National Wildlife Refuge and support of irrigated agriculture within the Amargosa Farms area (fig. 1). Recharge of ground water is a relatively uncharacterized component of the hydrologic budget. The basin is part of the larger Death Valley regional ground-water flow system. While numerous studies have examined the Death Valley system at a regional scale (Winograd and Thordarson, 1975; Harrill and others, 1988; D'Agnese and others, 1999; Tiedeman and others, 2004), the sparsely populated Amargosa Desert Basin-especially its upper reaches-has received relatively little study. Considerable uncertainties remain in subsurface residence times and fluxes under current climatic and land-use conditions. Appraisal of ground-water resources and management of competing demands from developing land-use patterns requires an improved understanding of ground-water recharge in this desert environment.

\section{Population, Land Use, and Water Withdrawals}

The Amargosa Desert Basin is sparsely populated and relatively undeveloped. The average population density is less than one person per square kilometer. Primary land uses are farming and recreation. The town of Beatty straddles the Amargosa River just upstream of its entry into the basin (fig. 1). The estimated population of Beatty in 2000 was 1,085 (U.S. Census Bureau, 2003). The Amargosa Farms area spreads across the outlet of the basin. The census division that includes the farms area, Amargosa Valley, had an estimated population in 2000 of 1,142 .

In view of rapid population growth in nearby areas, the Amargosa Desert Basin has substantial potential for growth. Population estimates at the county level extend back to 1870 . The early population of the county jumped roughly six-fold after prospectors found gold near Beatty in 1904, and rose again in the 1950s and 1960s during expansion of irrigated agriculture and defense activities at the Nevada Test Site (fig. 2). Even so, total county population remained below 10,000 before 1981 . 


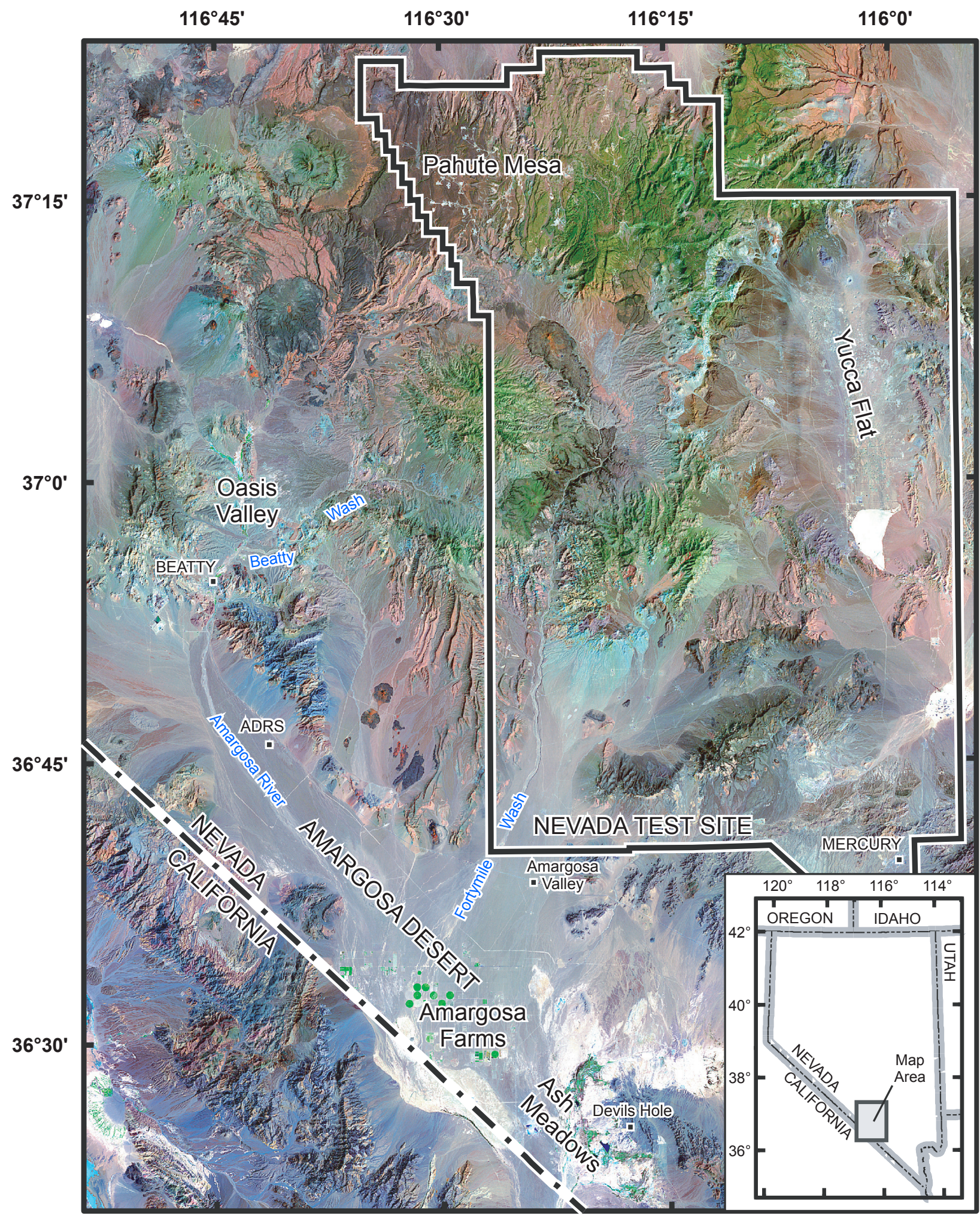

तागणागाणाणाणात

$\begin{array}{lllll}0 & 5 & 10 & 15 & 20 \text { Kilometers }\end{array}$

Figure 1. Physiographic and cultural features in the Amargosa Desert study area and vicinity, Nye County, Nev., and Inyo County, Calif. During the study, an active streamflow-gaging station was located in Beatty, Nev. Weather stations were located at Beatty, Nev., Amargosa Valley, Nev., Amargosa Farms, Nev., and at the ADRS (Amargosa Desert Research Site; Andraski and Stonestrom, 1999). Figure 9 shows channel- and borehole-sampling locations. 
The county grew substantially starting in the late 1970s due to migration into Pahrump Valley, an adjacent basin southeast of Ash Meadows.

The primary use of ground water in the Amargosa Desert Basin is for irrigation. Irrigation began around 1917 and continued on a modest scale until 1954. Between 1954 and 1965, the number of wells grew by about 150 to support agricultural production. Irrigation withdrawals have fluctuated since 1965, but maximum withdrawals about 20 million cubic meters per year $\left(\mathrm{Mm}^{3} \mathrm{yr}^{-1}\right)$ rival the natural discharge of ground water at Ash Meadows (about 22-26 $\mathrm{Mm}^{3} \mathrm{yr}^{-1}$; Laczniak and others, 1999; Stonestrom, Prudic, and others, 2003).

\section{Hydrogeologic Setting}

The Amargosa Desert Basin is bounded by large mountain blocks comprised of rocks ranging from Precambrian through Tertiary. Dominant rock types include Precambrian to Cambrian quartzite, Precambrian to Devonian massive dolomite and limestone, Carboniferous interbedded limestone and shale, and Tertiary rhyolites and basalts. Late Tertiary to Quaternary sediments form poorly indurated to unconsolidated basin-floor deposits (Winograd and Thordarson, 1975; Nichols, 1987; Sweetkind and others, 2001; Workman and others, 2002).

The present basin configuration resulted from distinct episodes and styles of tectonic deformation (Carr and Yount, 1984; Hamilton, 1987; Glazner and others, 2002; Park and Wernicke, 2003). Cretaceous folding and thrusting imparted an east-to-northeasterly grain to the Paleozoic bedrock. Tear faulting of low-angle overthrusted slabs followed, ending in mid-Tertiary (Carr and Yount, 1984). Tear faulting impacted the entire area, creating northwesterly striking offsets (tears) in bedrock units of tens of kilometers. A northeasterly trending corridor of folding and faulting divides the Amargosa Desert Basin into upper and lower regions. This corridor, marked by the lower reaches of Fortymile Wash, appears to have formed by the early Tertiary (Carr and Yount, 1984). Low-angle detachment faulting starting in mid Tertiary accompanied subcontinental extension, producing the horst and graben topography characteristic of the southern Great Basin (Hamilton, 1987). Horst and graben-style faulting associated with large-scale detachments locally activated preexisting northeasterly and northwesterly trending structures, forming deep basins that filled with alluvium. Widespread volcanism accompanied extension (Workman and others, 2002). Active deformation of $9 \mathrm{~mm} \mathrm{yr}^{-1}$ north-northwesterly trending right-lateral shear continues to shape the region (Park and Wernicke, 2003). Small blocks of bedrock crop out through basin-floor alluvium along a northwesterly trending line through the Amargosa Desert Research Site (Stonestrom and others, 2004). Tectonic subsidence in the central part of the Amargosa Farms area is roughly matched by alluvial deposition from the Amargosa River and Fortymile Wash (Stonestrom, Prudic, and others, 2003).

As part of the Mojave Desert ecosystem, the Amargosa Desert Basin is one of the driest areas in the United States.

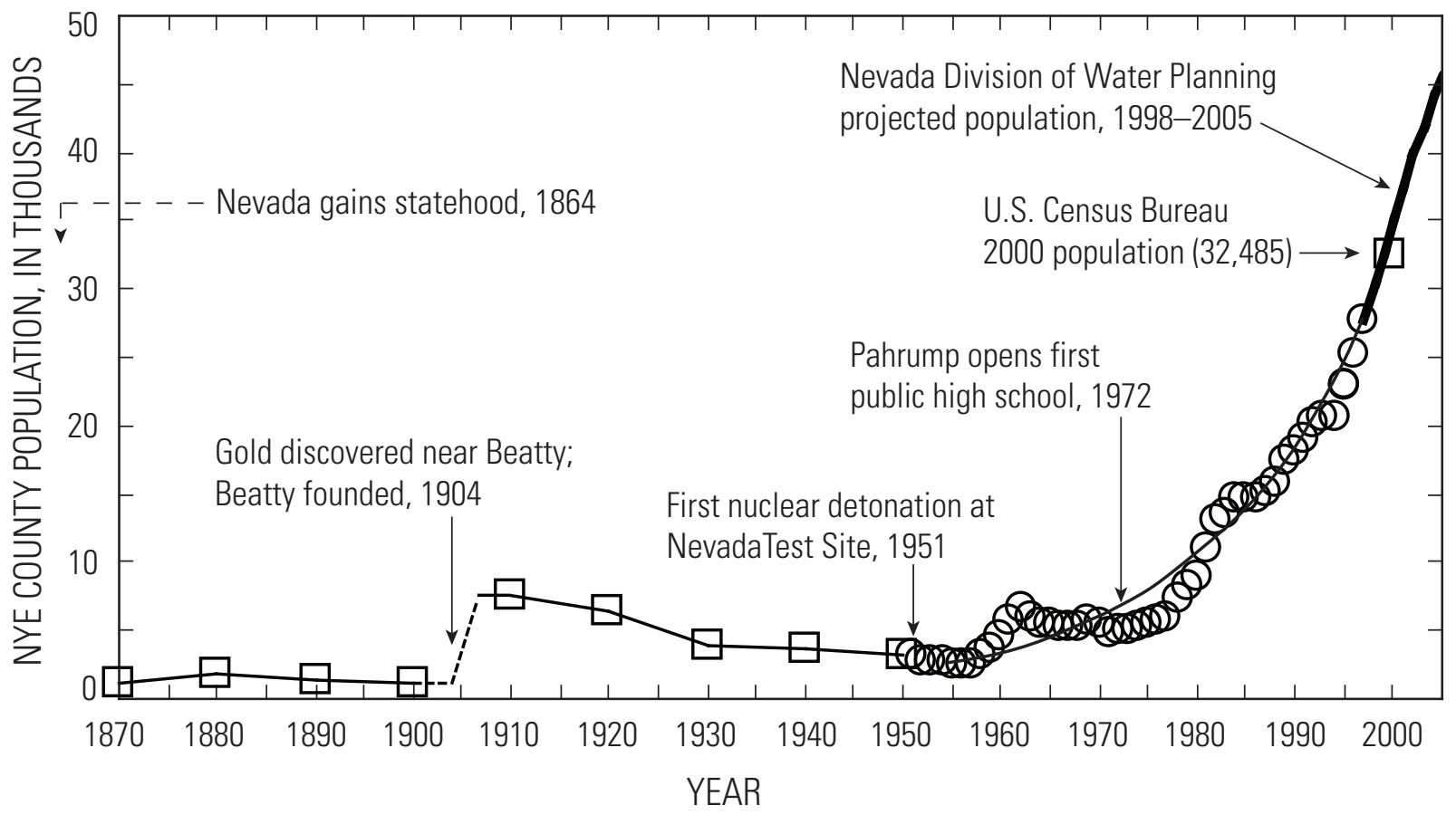

Figure 2. The population of Nye County, Nev., increased exponentially from the mid 1950s through mid 1990s, at about six percent per year (thin curved line). Early data (squares) are from the University of Virginia's Fisher Library (http://fisher.lib. virginia.edu/census, last accessed June 10, 2003). Later estimates (circles, 1950-1997) and forecasts (thick line, 1998-2005) are from the Nevada Division of Water Planning (http://www.water.nv.gov/waterPlanning/wat-plan/con-main.cfm; last accessed March 1, 2005). 
The present climate is arid-thermic, with moderate seasonality with respect to precipitation and strong seasonality with respect to temperature (Bull, 1991). Daily average temperatures range from 33 degrees Celsius $\left({ }^{\circ} \mathrm{C}\right)$ in August to $3^{\circ} \mathrm{C}$ in December (fig. 3). Precipitation on the basin floor averages about a tenth of a meter per year based on long-term records at Amargosa Farms (1971-2000; $99.6 \mathrm{~mm} \mathrm{yr}^{-1}$; NOAA, 2002) and at the Amargosa Desert Research Site (1981-2005; $112 \mathrm{~mm} \mathrm{yr}^{-1}$; Johnson and others, 2007). About 60 percent of annual precipitation arrives in frontal systems during the months of December through March, with enhanced amounts during moderate to strong El Niño events (fig. 4).

Ground-water discharge maintains perennial flow in the Amargosa River at Beatty, near the entrance to the basin. Base flow dissipates within a few kilometers downstream. Speculation that no modern-day flows were capable of completely traversing the Amargosa Desert Basin was falsified by field reconnaissance following storms in March 1995 that produced continuous flow from the Nevada Test Site to Death Valley (Beck and Glancy, 1995).

Except for storm-generated runoff, the Amargosa River is usually dry downstream of Beatty. Storm flows are brief- despite an upstream drainage area of about 1,200 square kilometers - as shown by 15-minute discharge data at Beatty during the study period (fig. 5). Ephemeral flow is generated primarily by runoff from the mountains surrounding Oasis Valley, but runoff from Bare Mountain (which forms the northeastern side of the basin), the Bullfrog Hills (northern side), the Funeral Mountains (southwestern side), as well as runoff from the basin floor itself can contribute flow in unnamed tributaries. Ephemeral flows exhibit extreme variability in magnitude, as shown by annual peak flows at the basin inlet (fig. 6).

The dominant plant in the Mojave Desert is creosote bush (Larrea tridentata; Smith, Monson, and others, 1997), which covers nearly the entire Amargosa Desert Basin floor. Saltbush (Atriplex) co-dominates, becoming dominant beside channel reaches that were scoured by major flooding in the past. The active channel is largely vegetation free. On surfaces more than a few meters away from the channel, the native vegetation has likely been undisturbed for many centuries. Creosote and saltbush plants are perennial, with several meters typically separating the above-ground portions of adjacent plants. Typical mature heights are $0.5 \mathrm{~m}$ (saltbush) to $1-2 \mathrm{~m}$ (creosote bush).

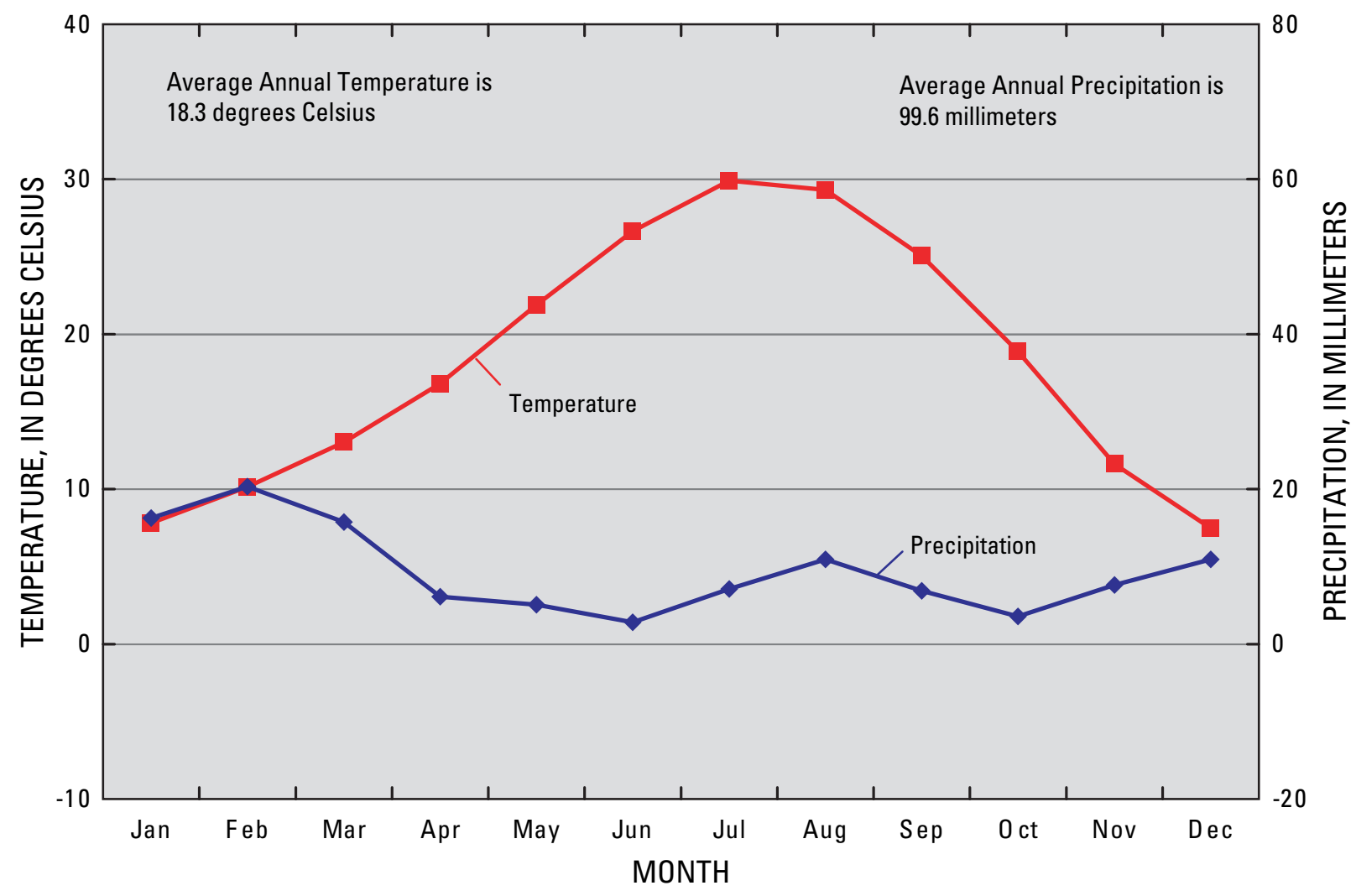

Figure 3. Mean monthly temperature and precipitation for 1965-2000 at Amargosa Farms, Nev. (National Weather Service cooperative station 260150). Altitude of station is 747 meters above sea level (National Geodetic Vertical Datum of 1929). 


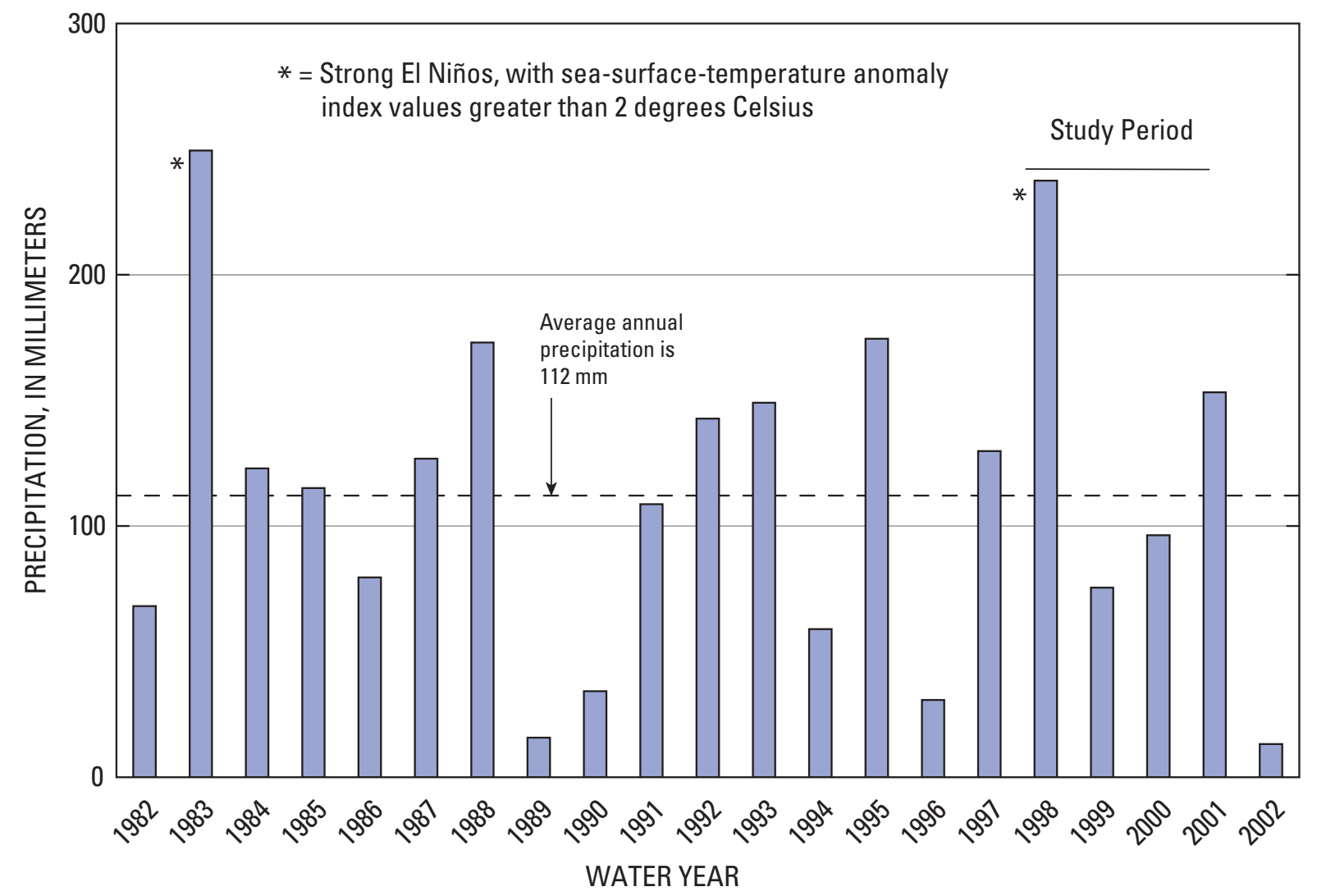

Figure 4. Annual precipitation at the Amargosa Desert Research Site (ADRS) for water years 1982-2002 (Johnson and others, 2007). El Niño index is from McPhaden and others (2006). Water year runs from October 1 to September 30 and is denoted by the calendar year in which it ends. Figure 1 shows the location of the Amargosa Desert Research Site.

In addition to these large perennials, a variety of small annuals quickly fill the intervening gaps after accumulation of more than a few millimeters of precipitation when conditions are favorable. At the entrance to the basin, perennial flow supports a salt-cedar-willow community along the Amargosa River.

Potential evapotranspiration in the Amargosa Desert Basin greatly exceeds precipitation on an annual basis. Nichols (1987) estimated potential evaporation to be $2.5 \mathrm{~m} \mathrm{yr}^{-1}$, exceeding average annual precipitation by a factor of 23 . Daily accounting of actual evaporation in conjunction with a waterbalance model showed that deep percolation (precipitation in excess of evaporation and soil-moisture replenishment) might have occurred beneath non-vegetated surfaces on three separate occasions during 1961-1976, in amounts ranging from 5 to $26 \mathrm{~mm}$ (Nichols, 1987).

Micrometeorological and soil data from the Amargosa Desert Research Site clearly show the decisive role of desert vegetation in controlling the near-surface water balance. Early work indicated that removal of vegetation for five years (1987-1992) reversed the potential gradient for water movement, from upward to downward, in a gradually deepening layer (Andraski, 1997). Measured evapotranspiration from native vegetation $(48 \mathrm{~mm})$ exceeded total precipitation $(3.5 \mathrm{~mm})$ by a factor of 13.7 in 2002 (Johnson and others, 2007). A net decrease in soil moisture during 2002 made up the difference. Precipitation data at Beatty show that 2002 was the driest year in 64 years of record. Lysimeter data for the same plant association on the Nevada Test Site showed that complex feedbacks between native vegetation and available moisture maintained upward gradients for water movement from 1994 through 2001 (Scanlon and others, 2005). Due to increased plant vigor, upward gradients strengthened rather than weakened in response to the period of El Niño enhanced precipitation during 1997-1998.

\section{Previous Work and Scope}

Relatively few studies have examined ground-water recharge in the Amargosa Desert Basin. Walker and Eakin (1963) provided an early reconnaissance estimate based on earlier work in east-central Nevada, where recharge (assumed to be equal to ground-water discharge through springs and evapotranspiration) in 13 closed basins was correlated with precipitation (Maxey and Eakin, 1949; Eakin and Maxey, 1951; Avon and Durbin, 1994). Walker and Eakin divided the greater Amargosa area into precipitation zones. The current study area is entirely in the driest precipitation zone (less than $200 \mathrm{~mm}$ ), in which recharge was estimated to be zero. 

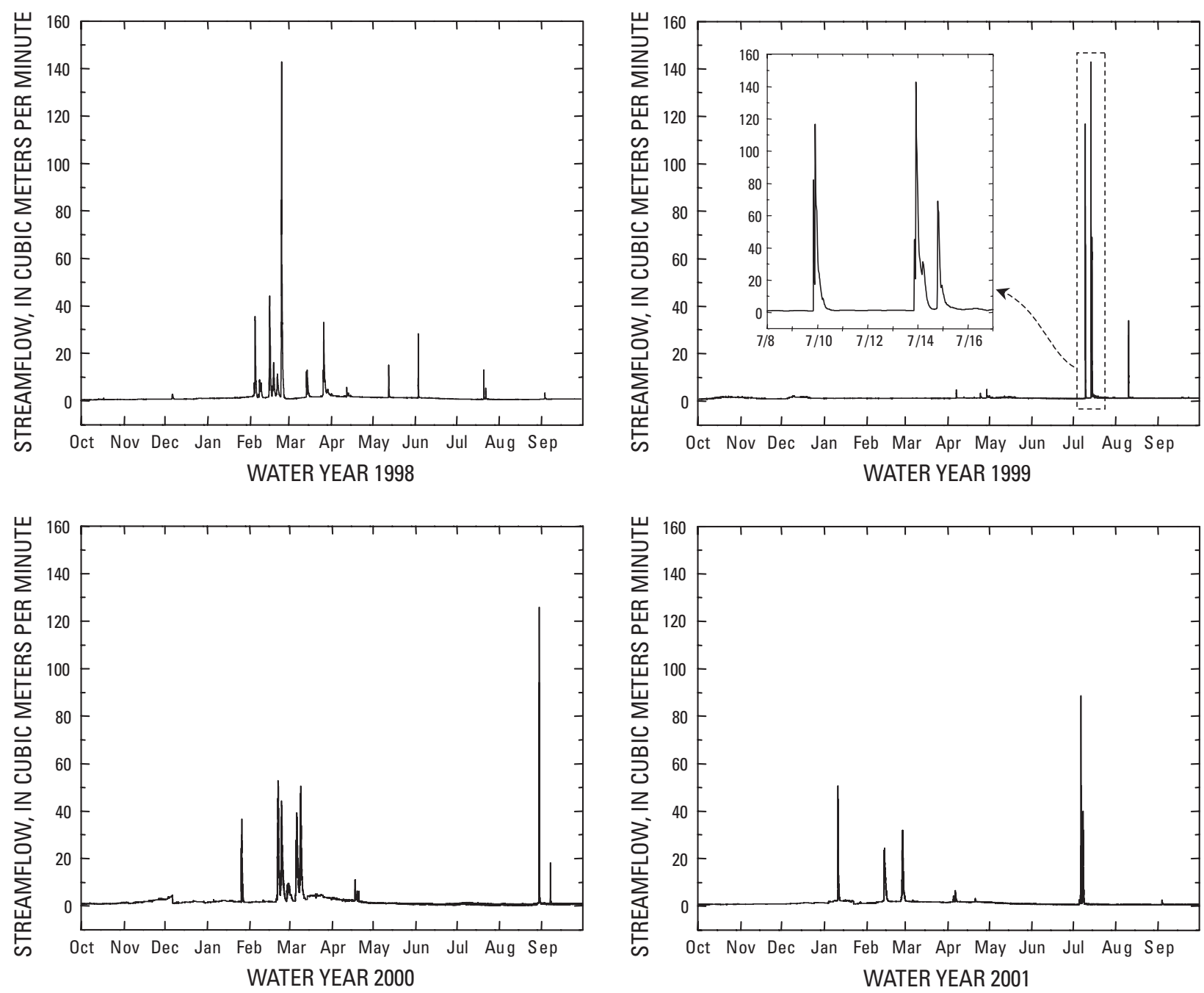

Figure 5. Discharge of the Amargosa River at Beatty, Nev., for water years 1998-2001 (USGS streamflow-gaging station 10251217). Inset shows detailed record for three stormflow events in July 1999. Under typical (non-storm) conditions, all base flow is lost to infiltration and evaporation within a few kilometers of the gage.

Claassen (1985) examined the geochemical composition of ground water in the west-central part of the basin and concluded that recharge was primarily from direct infiltration of overland flow in or near present day stream channels, rather than from subsurface inflows from the surrounding mountains. Depletion of stable isotopes oxygen-18 and deuterium in water indicate that most of the recharge originated as snowmelt. Carbon-14 dates indicate that most of the sampled ground water recharged during late Wisconsin to early Holocene time, with unadjusted ages ranging from 9 to 17 thousand years before present.

Osterkamp and others (1994) used a distributed-parameter water-balance approach to estimate recharge arising from contemporary streambed infiltration. This approach classified the Amargosa River into geomorphically similar reaches and assumed that all infiltration became recharge. Between the basin entrance near Beatty and outlet near Amargosa Farms, channel losses produced a total estimated annual recharge of 0.5 million cubic meters per year $\left(\mathrm{Mm}^{3} \mathrm{yr}^{-1}\right)$.

The geographic focus of the current study is the portion of the basin through which the Amargosa River flows. In addition, Beatty Wash - the largest tributary upstream of the Amargosa Desert - was instrumented near its confluence with the Amargosa River, in Oasis Valley (fig. 1). The study also considered recharge from irrigation return in the Amargosa Farms area near the downstream end of the study reach. The primary data for the study are from water-years 1998 through 2001, which spanned a range of wet to dry conditions (fig. 4). In addition to developing recharge estimates, the goal of the study was to gain understanding of recharge processes and controls, with particular regard to the timing and extent of recharge-producing events. 


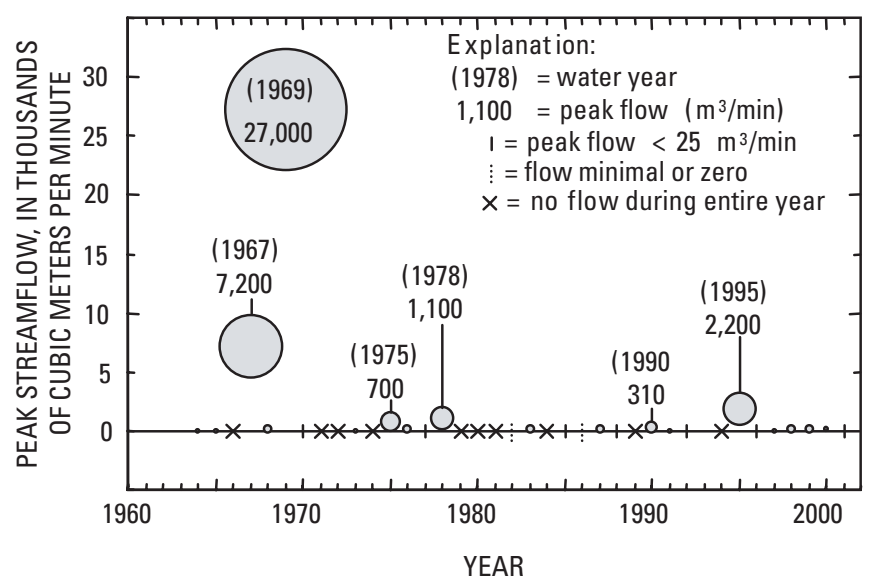

\section{Methods}

This study combined thermal flow detection with analyses of vertical profiles of water potential and naturally occurring environmental tracers to characterize infiltration and recharge within the Amargosa Desert Basin. Sampling locations included sites within the channel, irrigated fields, and beneath undisturbed native vegetation on the basin floor. Direct-current (DC) resistivity imaging, a surface geophysical technique, allowed generalization of results obtained at the limited number of sampled sites to areas of the basin with similar geomorphology and vegetation. This section briefly describes instrumentation, sampling, and data analysis.

Detailed descriptions appear in cited references.

Streambed-temperature anomalies indicated ephemeral flow at instrumented locations (Constantz and others, 2001; Stewart, 2003; table 1). Measurement techniques included deployment of single-channel temperature loggers at a nominal depth of $0.1 \mathrm{~m}$ in channel sediment, nested thermocouples near the inlet to the basin and at the Amargosa Desert Research Site, and borehole-temperature loggers at two locations in the channel (Stonestrom and Blasch, 2003). Streambed-temperature measurements were supplemented by peak-flow estimates by using slope-conveyance and slope-area techniques (Benson and Dalrymple, 1967; Dalrymple and Benson, 1968).

Sediment samples were obtained from boreholes within the channel (sites $\mathrm{C} 1$ and $\mathrm{C} 2$ ), beneath native vegetation near the Amargosa Desert Research Site (ADRS) and Amargosa Farms area (sites ADRS and AFNV), and beneath irrigated fields (sites AF-A1-AF-C2; table 2; fig. 7). Water potentials for each sample were determined with a water-activity meter (Gee and others, 1992). Gravimetric water contents were determined by oven drying at $105^{\circ} \mathrm{C}$ (Gardner, 1986). Pore-water chemistry was characterized by using methods in Page and others (1982) and Sparks (1996). Each oven-dried sample was mixed with an equal mass of deionized water and shaken periodically for 24 hours. Supernatant liquid was filtered and analyzed for chloride and nitrate by using ion chromatography. Supernatant
Figure 6. Annual peak flows, Amargosa River near Beatty, Nev., for October 1963 through September 2001. Data for water years 1964-1968 and 1991-1995 are from USGS streamflowgaging station 10251218, $3.7 \mathrm{~km}$ downstream of station 10251217 (Amargosa River at Beatty, Nev.; temperature station PS-1). Data for water years 1969-1990 are from crest-stage partial-record station 10251220 (at PS-2), $5.4 \mathrm{~km}$ downstream of the Beatty gage. Data for water years 1996-2002 are from the Beatty gage. No gages were active in water years 1982 and 1986; however, flows were zero or small. The channel downstream of 10251220 is dry more than 98 percent of the time. The 1969 flood was the largest on record, producing a peak flow that exceeded the median annual peak flow by more than two orders of magnitude. From Stonestrom, Prudic, and others (2004).

concentrations were converted to pore-water concentrations by dividing by gravimetric water contents and multiplying by the pore-water density (assumed to be $1.00 \times 10^{6} \mathrm{gram} \mathrm{m}^{-3}$ ). Volumetric water contents were obtained by multiplying gravimetric water content by bulk densities estimated on the basis of lithologic description. Unsaturated-zone chloride-mass-balance and tracer-velocity techniques provided estimates of deep percolation and recharge (Stonestrom, Prudic, and others, 2003). Water for stable isotopic analysis was extracted by complete-recovery cryodistillation (Prudic and others, 1997).

Surface-based DC-resistivity measurements were made in May of 2003 along transects normal to the sedimentary depositional fabric in three distinct geomorphologic settings; one where the Amargosa channel is incised into the adjacent terrace sediments (near PS-4), one where the channel forms an actively migrating distributory network (near PS-6E), and one on the alluvial surface adjacent to the ADRS. Water years 2002 and 2003 were dry, producing no flows that extended more than a few kilometers into the basin. At each resistivity transect, linear arrays of 32 to 80 electrodes were deployed with a uniform 2 to 5-m spacing between adjacent electrodes. A multiplexing 8-channel resistivity instrument was used to make automated resistivity measurements along the line, combining sounding and profiling for vertical and horizontal resolution (fig. 8; Stonestrom, Abraham, and others, 2003; Abraham and Lucius, 2004). Each measurement used four electrodes at a time, with geometry varying between inverse-Schlumberger and inverse-Wenner configurations (Telford and others, 1990). Sodium-chloride solution was used to improve electrical contact between electrodes and the extremely dry surface soil. Imposed currents ranged from 250 to 400 milliamps. The line was shifted incrementally until composite transects consisted of 168 to 232 electrode positions. Each transect produced vertical arrays of 3,000 to 4,000 apparent resistivity soundings.

Apparent resistivity soundings were used in a constrained inversion scheme, generating a model distribution of subsurface DC resistivities based on the difference between measured and predicted apparent resistivities. The inversion 
Table 1. Locations of streamflow-gaging station and peak-flow- and temperature-measurement sites, Amargosa Desert study area.

\begin{tabular}{llcccc}
\hline \multicolumn{1}{c}{ Description } & Code & $\begin{array}{c}\text { Latitude', } \\
\text { in degrees }\end{array}$ & $\begin{array}{c}\text { Longitude', } \\
\text { in degrees }\end{array}$ & $\begin{array}{c}\text { Altitude }{ }^{2}, \\
\text { in meters }\end{array}$ & $\begin{array}{c}\text { Distance from } \\
\text { basin inlet, } \\
\text { in kilometers }\end{array}$ \\
\hline Beatty Wash & BW & 36.9434 & 116.7190 & 1049 & -8.3 \\
Amargosa River at Beatty (station 10251217) & GAGE & 36.9106 & 116.7564 & 1003 & -3.0 \\
Amargosa River near highway 95 bridge & PS-1 & 36.8802 & 116.7525 & 966 & 0.8 \\
Amargosa River near airport road & PS-2 & 36.8678 & 116.7595 & 954 & 2.4 \\
Amargosa River near highway 95 bend & PS-3 & 36.8595 & 116.7570 & 942 & 3.4 \\
Amargosa River near beacon road & PS-4 & 36.7979 & 116.7555 & 888 & 10.6 \\
Unnamed tributary near beacon road & PS-4T & 36.7932 & 116.7647 & 887 & NA \\
Amargosa River west of ADRS & PS-5 & 36.7658 & 116.7323 & 859 & 14.9 \\
Amargosa River near Ashton site, east channel & PS-6E & 36.7111 & 116.6772 & 807 & 22.9 \\
Amargosa River near Ashton site, west channel & PS-6W & 36.7066 & 116.6805 & 805 & 22.9 \\
Unnamed tributary near Ashton site & PS-6T & 36.6887 & 116.6880 & 799 & NA \\
Amargosa River near Big Dune & PS-7 & 36.6324 & 116.6111 & 749 & 33.7 \\
\hline
\end{tabular}

${ }^{1}$ North latitude and west longitude; North American Datum of 1927.

${ }^{2}$ Land surface altitude, National Geodetic Vertical Datum of 1929.

${ }^{3}$ Measured from gap in bedrock at entrance to basin, $3.0 \mathrm{~km}$ downstream of USGS streamflow-gaging station 10251217 (Amargosa River at Beatty, Nev.). Negative value is distance upstream; positive is distance downstream.

${ }^{4} \mathrm{NA}$ - not applicable.

${ }^{5}$ ADRS is the Amargosa Desert Research Site (Andraski and Stonestrom, 1999; http://nevada.usgs.gov/adrs/).

Table 2. Locations of sampled boreholes within the Amargosa Desert study area.

\begin{tabular}{llcccc}
\hline \multicolumn{1}{c}{ Description } & Code & $\begin{array}{c}\text { Latitude', } \\
\text { in degrees }\end{array}$ & $\begin{array}{c}\text { Longitude', } \\
\text { in degrees }\end{array}$ & $\begin{array}{c}\text { Altitude } \\
\text { in meters }\end{array}$ & $\begin{array}{c}\text { Borehole depth, } \\
\text { in meters }\end{array}$ \\
\hline Amargosa channel site 1, at PS-4 & C1 & 36.7981 & 116.7525 & 889 & 14 \\
Amargosa channel site 2, at PS-6E & C2 & 36.7131 & 116.6764 & 808 & 14 \\
ADRS ${ }^{3}$, native vegetation & ADRS & 36.7656 & 116.6936 & 847 & 48 \\
Amargosa farms, native vegetation & AFNV & 36.5656 & 116.5261 & 724 & 15 \\
Amargosa farms, field 1, hole A & AF-1A & 36.5647 & 116.5261 & 723 & 12 \\
Amargosa farms, field 1, hole B & AF-1B & 36.5622 & 116.5275 & 722 & 15 \\
Amargosa farms, field 2, hole A & AF-2A & 36.5536 & 116.5264 & 719 & 10 \\
Amargosa farms, field 2, hole B & AF-2B & 36.5497 & 116.5325 & 717 & 10 \\
Amargosa farms, field 3, hole A & AF-3A & 36.5461 & 116.4897 & 717 & 15 \\
Amargosa farms, field 3, hole B & AF-3B & 36.5442 & 116.4917 & 718 & 16 \\
\hline
\end{tabular}

${ }^{1}$ North latitude and west longitude; North American Datum of 1927.

${ }^{2}$ Land surface altitude, National Geodetic Vertical Datum of 1929.

${ }^{3}$ Composited data from boreholes at the Amargosa Desert Research Site (see Stonestrom, Prudic, and others, 2004). 


\section{A. Native Vegetation}

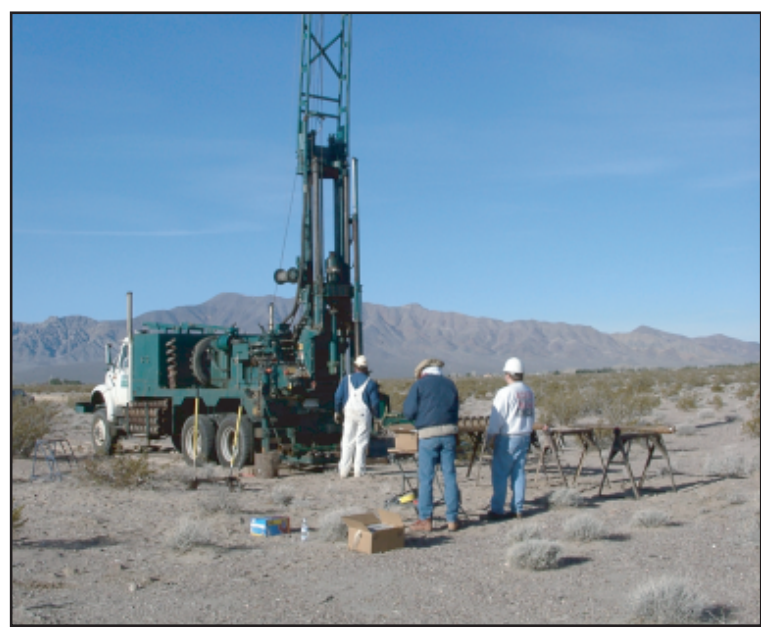

C. Irrigated Field

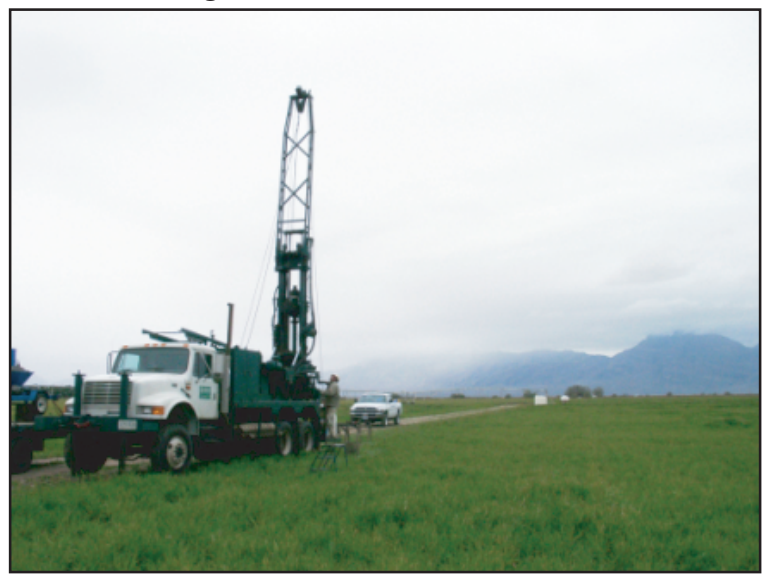

B. Amargosa River Channel

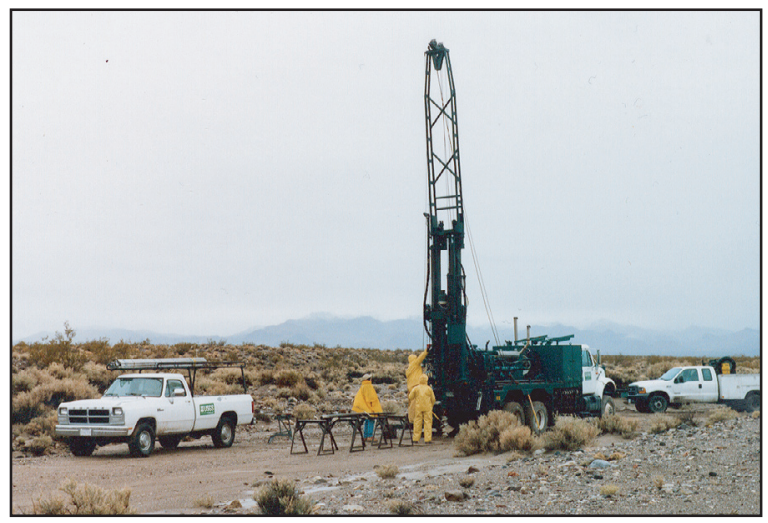

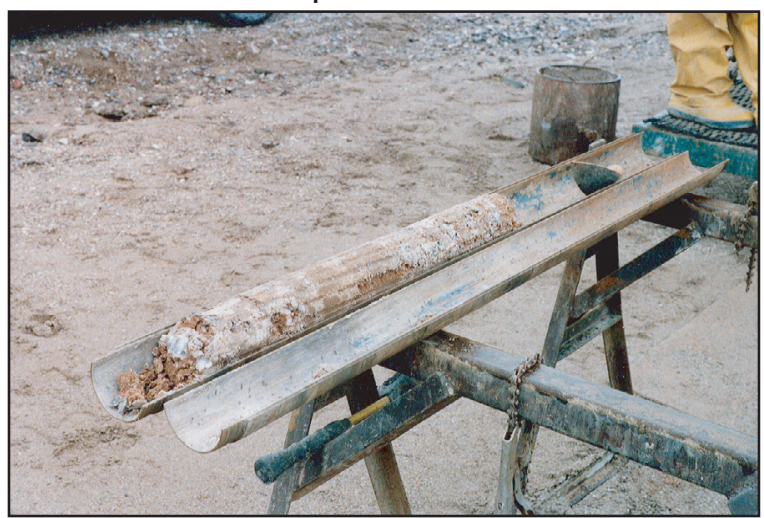

Figure 7. Photographs of unsaturated-zone sediment sampling in the Amargosa Desert study area. $A$, Native vegetation, Amargosa Farms; $B$, Amargosa River channel; $C$, irrigated field; $D$, sediment core from channel.

assumed an exponential distribution of data errors, minimizing an L1-norm of combined data misfits and model stabilization constraints (Abraham and Lucius, 2004). Figure 9 shows the locations of resistivity transects, unsaturated-zone sampling boreholes, and temperature measurement sites.

\section{Results and Discussion}

\section{Streamflow Characteristics}

The volume of water passing the USGS streamflowgaging station at Beatty, Nev. (10251217; "Beatty gage" hereafter) during the four-year study period was 3.03 million cubic meters $\left(\mathrm{Mm}^{3}\right)$, averaging $0.76 \mathrm{Mm}^{3}$ per year (table 3; fig. 5). Even though precipitation during the study period was greater than the long-term average- -25 percent greater at the
ADRS, for example-the streamflow represents only a small fraction (less than 4 percent on an average annual basis) of historic maximum ground-water withdrawals in the Amargosa Farms area. Ranking the daily average flows, a sharp inflection point separates base flow from storm runoff at about 2.5 cubic meters per minute $\left(\mathrm{m}^{3} \mathrm{~min}^{-1}\right)$. Base flow dominates the record in terms of duration and volume. About 95 percent (1389 of 1461) of daily average flows were less than $2.5 \mathrm{~m}^{3}$ $\mathrm{min}^{-1}$. From a volume standpoint, roughly three quarters of the discharge at the Beatty gage during the four-year period-2.26 $\mathrm{Mm}^{3}$ of $3.03 \mathrm{Mm}^{3}$-was base flow. The dominance of base flow into the Amargosa Desert Basin contrasts sharply with the dominance of storm flow in the Abo Arroyo portion of the middle Rio Grande Basin (chapter D, this volume), reflecting weaker monsoonal influences, higher aridity, and the relatively permeable rocks and sediments of the Amargosa headwaters compared to the Abo Arroyo headwaters. 

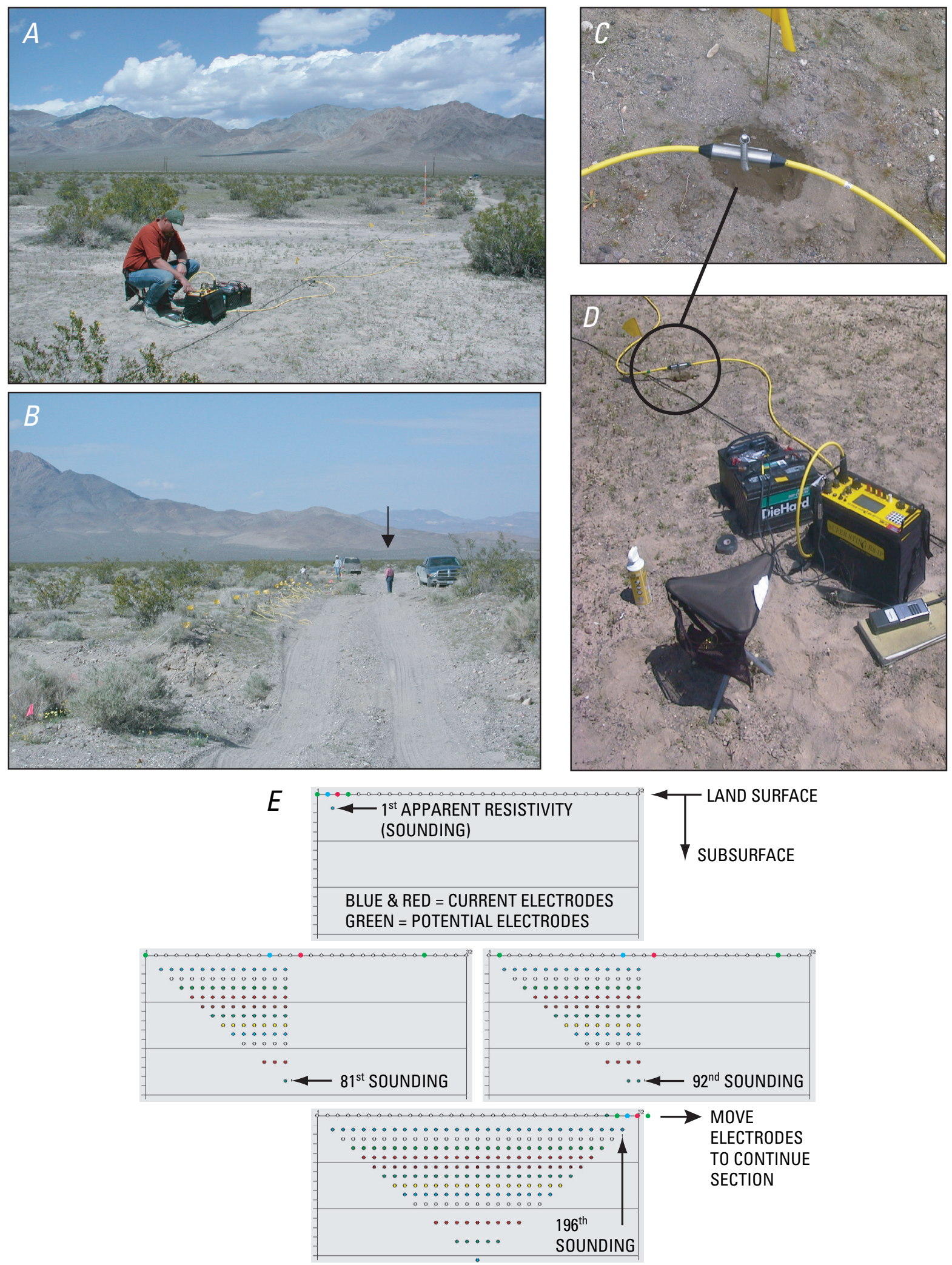

Figure 8. Direct-current resistivity imaging in the Amargosa Desert study area. $A$, Transect near Amargosa Desert Research Site (ADRS; Andraski and Stonestrom, 1999); B, transect across Amargosa River channel (arrow points to person in channel); $C$, electrode (stainless steel stake); with wetted sediment around electrode to decrease contact resistance; $D$, multiplexing resistivity meter; $E$, sequence of measurements. 


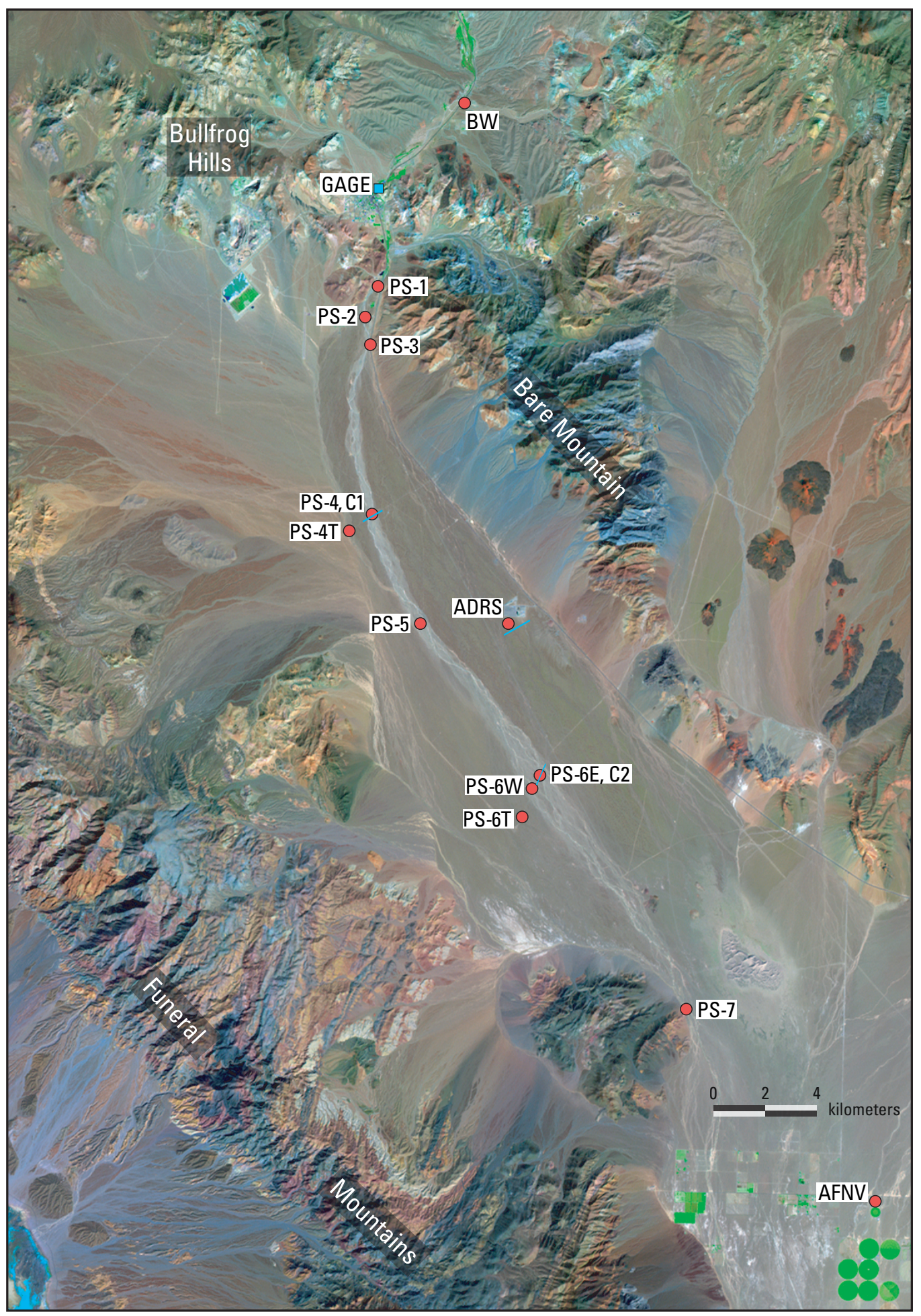

Figure 9. Detailed locations of temperature sites, resistivity transects, and unsaturated-zone boreholes in the Amargosa Desert study area. Temperature-measurement sites are denoted by PS-number (table 1). ADRS and AFNV denote boreholes in undisturbed native vegetation at the Amargosa Desert Research Site and in the Amargosa Farms area (table 2). Additional boreholes in irrigated fields south and southeast of AFNV (not shown) are listed in table 2. Resistivity transects are denoted by blue lines near probe sites PS-4, PS-6, and borehole ADRS. Blue square (GAGE) denotes the USGS streamflow-gaging station at Beatty, Nev. (10251217). Figure 1 shows the study-area location with latitudes and longitudes. 
Table 3. Amargosa River flow at Beatty, Nev. (USGS streamflow-gaging station 10251217) for water years 1998-2001. Summary daily statistics and total storm-flow versus base-flow volumes.

\begin{tabular}{|c|c|c|c|c|c|c|c|}
\hline $\begin{array}{l}\text { Water } \\
\text { year }^{1}\end{array}$ & $\begin{array}{c}\text { Median daily } \\
\text { average flow, } \\
\text { in cubic meters } \\
\text { per minute }\end{array}$ & $\begin{array}{l}\text { Maximum daily } \\
\text { average flow, } \\
\text { in cubic meters } \\
\text { per minute }\end{array}$ & $\begin{array}{l}\text { Minimum daily } \\
\text { average flow, } \\
\text { in cubic meters } \\
\text { per minute }\end{array}$ & $\begin{array}{c}\text { Total } \\
\text { volume } \\
\text { in millions } \\
\text { of cubic } \\
\text { meters }\end{array}$ & $\begin{array}{c}\text { Storm-flow } \\
\text { volume } \\
\text { in millions } \\
\text { of cubic } \\
\text { meters }\end{array}$ & $\begin{array}{c}\text { Base-flow } \\
\text { volume } \\
\text { in millions of } \\
\text { cubic meters }\end{array}$ & $\begin{array}{l}\text { Base-flow } \\
\text { volume, } \\
\text { in percent- } \\
\text { age of total } \\
\text { volume }\end{array}$ \\
\hline $1998^{3}$ & 1.1 & 37 & 0.42 & 0.88 & 0.36 & 0.52 & 59 \\
\hline $1999^{3}$ & 1.2 & 19 & 0.41 & 0.69 & 0.08 & 0.61 & 89 \\
\hline $2000^{3}$ & 1.0 & 13 & 0.46 & 0.73 & 0.17 & 0.56 & 77 \\
\hline $2001^{4}$ & 0.9 & 20 & 0.55 & 0.74 & 0.17 & 0.56 & 77 \\
\hline \multicolumn{8}{|c|}{ Four-year study period } \\
\hline $\begin{array}{l}1998- \\
2001\end{array}$ & 1.1 & 37 & 0.41 & 3.0 & 0.78 & 2.3 & 74 \\
\hline
\end{tabular}

\footnotetext{
${ }^{1}$ Water year is October 1 through September 30 and denoted by calendar year in which it ends.

${ }^{2}$ Values rounded for reporting purposes. Calculations used unrounded numbers.

${ }^{3}$ Water-year statistics derived from daily means obtained at http://waterdata.usgs.gov/nwis; accessed January 3, 2007.

${ }^{4}$ Statistics derived from daily means of 15 -minute data.
}

The strongest El Niño of the modern instrumental record (post 1981) produced increased precipitation during the first year of the study period (Curtis and Adler, 2000; Vecchi and others, 2006). Rainfall at the ADRS in water year 1998 was $238 \mathrm{~mm}$, more than twice the long-term average (Johnson and others, 2002). February was the wettest month, accounting for about 42 percent of annual precipitation. Frontal systems moving through the region resulted in several flows into the Amargosa Desert Basin, with peak flows at the Beatty gage larger than $20 \mathrm{~m}^{3} \mathrm{~min}^{-1}$ on two occasions by mid month, February 4, $1998\left(36 \mathrm{~m}^{3} \mathrm{~min}^{-1}\right)$ and February 15, $1998\left(44 \mathrm{~m}^{3} \mathrm{~min}^{-1}\right)$. These storms were followed by a large, slow-moving system that produced widespread flooding on February 23-24. The largest flow of the study period, about $150 \mathrm{~m}^{3} \mathrm{~min}^{-1}$, occurred on February 23 (fig. 5).

Other large runoff events occurred in July 1999, August 2000, and July 2001 (fig. 5). Of these, only the July 1999 flows traversed more than a few kilometers into the Amargosa Desert Basin. The July 1999 flows stemmed from a stationary region of high-pressure that started building over the fourcorners region early in the month. Associated anticylonic circulation transported subtropical moisture from the Gulf of California into the Amargosa area. Flashy runoff from convective storms was recorded by the Beatty gage on July 9 , 13, and 14 (fig. 5).

Site visits following large storms established the extent and peak rates of flow. Table 4 shows estimated peak flows for storms during the study period that produced peak flows at the Beatty gage exceeding $80 \mathrm{~m}^{3} \mathrm{~min}^{-1}$. Peak-flow estimates were made by using the slope-area method, where the energy gradient was determined by detailed surveying of high-water marks, and the slope-conveyance method, where the gradient is approximated by the channel slope. Whereas slope-area estimates are more accurate, they too are uncertain (Jarrett, 1987). In both cases the largest errors are systematic, making relative changes instructive.

An actively used road to a mining operation crosses the channel near PS-2, 2.4 kilometers from the entrance to the basin (fig. 9). The unpaved road lacked culverts and was regraded following flow events that extended into the basin past the road. The February 1998 flows readily breached a low roadbed, judging from high-water marks upstream and downstream of the road. The first of the July 1999 flows breached a higher roadbed, which acted as a temporary dam. Thus, peak flows of the July 1999 event downstream of PS-1 were artificially increased by the sudden release of ponded water.

Streamflow passing through the Beatty gage is generally lost to seepage within a few kilometers of entering the Amargosa Desert Basin. The storm-generated flow of February 23-24, 1998 passed through the entire basin, extending from the Nevada Test Site to Death Valley (Tanko and Glancy, 2001). The peak flow rate was estimated to be $156 \mathrm{~m}^{3} \mathrm{~min}^{-1}$ at Beatty (90 cubic feet per second) and $36 \mathrm{~m}^{3} \mathrm{~min}^{-1}$ at Big Dune (20 cubic feet per second). These estimates indicate that $120 \mathrm{~m}^{3}$ $\mathrm{min}^{-1}$ of flow were lost along the reach, if lateral inflows were negligible. Assuming a uniform loss rate, the average loss rate was about $3.4 \mathrm{~m}^{3} \mathrm{~min}^{-1}$ per kilometer. This suggests that a flow event with a peak rate of at least $44 \mathrm{~m}^{3} \mathrm{~min}^{-1}$ at the Beatty gage would reach channel site $\mathrm{C} 1$, the instrumented borehole at PS-4, and similarly $85 \mathrm{~m}^{3} \mathrm{~min}^{-1}$ would reach channel site $\mathrm{C} 2$, the instrumented borehole at PS-6E. Site C1 and C2, respectively, are 13.6 and $25.9 \mathrm{~km}$ downstream of the Beatty gage. 
Table 4. Estimates of peak flow in the Amargosa River and its main tributaries in the Amargosa Desert study area for major runoff events during water years 1998-2001.

$[<$, less than; , approximately]

\begin{tabular}{lcccc}
\hline \multicolumn{1}{c}{$\begin{array}{c}\text { Brief description and site } \\
\text { code }^{1}\end{array}$} & $\begin{array}{c}\text { February 23-24, } \\
\mathbf{1 9 9 8}\end{array}$ & $\begin{array}{c}\text { July 13, } \\
\mathbf{1 9 9 9}\end{array}$ & $\begin{array}{c}\text { August 30, } \\
\mathbf{2 0 0 0}\end{array}$ & $\begin{array}{c}\text { July 7, } \\
\mathbf{2 0 0 1}\end{array}$ \\
\hline Beatty Wash (BW) & $39(51)$ & 0 & 0 & 204 \\
Beatty gage (GAGE $\left.{ }^{2}\right)$ & $143(153)$ & 143 & 126 & 88 \\
Highway 95 bridge (PS-1) & 117 & 51 & minor & 3 \\
Airport road (PS-2) & 65 & 204 & $\sim 0^{3}$ & $<0.2$ \\
Bend (PS-3) & 56 & 119 & $\sim 0^{3}$ & $-^{4}$ \\
Beacon road (C1) & 39 & 76 & 0 & $-^{4}$ \\
Beacon tributary (PS-4T) & 0 & $\sim 0^{3}$ & $\sim 0^{3}$ & $\mathbf{-}^{4}$ \\
West of ADRS (PS-5) & 53 & 51 & $\sim 0^{3}$ & $-^{4}$ \\
Ashton east branch (C2) & 39 & 8 & $\sim 0^{3}$ & 0 \\
Ashton weat branch (PS-6W) & 24 & 17 & $\sim 0^{3}$ & 0 \\
Ashton tributary (PS-6T) & 0 & 0 & 0 & 0 \\
Big Dune (PS-7) & $16(34)$ & 2 & 0 & 0 \\
\hline
\end{tabular}

${ }^{1}$ Tables 1 and 2 give site locations.

${ }^{2}$ Sites not at USGS streamflow-gaging station 10251217-Amargosa River at Beatty, Nev. (GAGE) were estimated by slope-conveyance method. Slope-area estimates, where available, are in parentheses.

${ }^{3}$ Peak flow too small to measure (approximately zero) — evidence of sheet flow or segmented flow and local ponding only.

${ }^{4}$ Site not visited, but presumed to have had no flow.

To characterize the frequency of flows capable of reaching $\mathrm{C} 1$ and $\mathrm{C} 2$, data from stream-gaging stations at Beatty (including historic partial-record crest-stage stations listed in the caption to fig. 6) were compiled for the 37-year period of record. Flow events with a peak discharge greater than $44 \mathrm{~m}^{3} \mathrm{~min}^{-1}$ occurred on at least 26 occasions (Stonestrom, Prudic, and others, 2003). Flows with peaks greater than 85 $\mathrm{m}^{3} \mathrm{~min}^{-1}$ occurred on at least 16 occasions. Not all flows were documented, as only annual peak discharges were recorded in most years. The largest flow on record occurred on February 24, 1969 (fig. 6). This flood peaked at about 27,000 $\mathrm{m}^{3} \mathrm{~min}^{-1}$, surpassing other flows by a factor of 3.8 (Moosburner, 1978).

Flow durations were characterized with data from the Beatty gage, where stage was recorded every 15 minutes from August 1993 to April 1995 and from January 1996 to October 2001. Flow was divided into 4 categories: 0 to $6 \mathrm{~m}^{3}$ $\mathrm{min}^{-1}$, greater than 6 to $44 \mathrm{~m}^{3} \mathrm{~min}^{-1}$, greater than 44 to $85 \mathrm{~m}^{3}$ $\mathrm{min}^{-1}$, and greater than $85 \mathrm{~m}^{3} \mathrm{~min}^{-1}$. Flow at the Beatty gage was less than $6 \mathrm{~m}^{3} \mathrm{~min}^{-1}$ about 99 percent of the time. Flows greater than $44 \mathrm{~m}^{3} \mathrm{~min}^{-1}$ occurred only about 0.13 percent of the time. Flows greater than $85 \mathrm{~m}^{3} \mathrm{~min}^{-1}$ occurred only about
0.04 percent of the time. Assuming no lateral inflow from tributary channels, and a uniform loss rate, the estimated total duration of flow at $\mathrm{C} 1$ is about $11 \mathrm{hr} \mathrm{yr}^{-1}$ at $\mathrm{C} 1$ and 3.5 $\mathrm{hr} \mathrm{yr}^{-1}$ at $\mathrm{C} 2$. Average seepage losses during flow events, assuming an average channel width of three meters, is about 1.1 millimeters per minute, or 68 millimeters per hour. Multiplying this rate by 11 hours yields an annual infiltration rate of about $0.75 \mathrm{~m} \mathrm{yr}^{-1}$ at C1. Similarly, multiplying by 3.5 hr yields an annual infiltration rate of about $0.24 \mathrm{~m} \mathrm{yr}^{-1}$ at $\mathrm{C} 2$ (table 5). These estimates are approximate and do not consider possible additions from tributaries or direct runoff from the basin floor. They also do not consider antecedent conditions and variations in channel width. Nevertheless, the data indicate that seepage losses occur throughout the study reach.

\section{Thermal Detection of Streamflow and Infiltration}

Streambed thermal anomalies provided detailed information on the extent and duration of flows. Figure 10 shows precipitation, streamflow, and example thermographs for the 
Table 5. Infiltration- and recharge-flux densities as estimated from pore-water concentrations of chloride and nitrate in contrasting hydrologic settings, Amargosa Desert study area.

$\left[\mathrm{m} / \mathrm{yr}\right.$, cubic meters of water per square meter of land surface per year; $\mathrm{g} / \mathrm{m}^{2} \mathrm{yr}$, grams per square meter of land surface per year; $\mathrm{g} / \mathrm{m}^{3}, \mathrm{grams}$ per cubic meter of pore water; $\mathrm{m}^{3} / \mathrm{m}^{3}$, cubic meter of pore water per cubic meter of bulk sediment]

\begin{tabular}{|c|c|c|c|c|c|c|c|c|c|}
\hline $\begin{array}{l}\text { Borehole } \\
\text { code }^{1}\end{array}$ & $\begin{array}{l}\text { Infiltra- } \\
\text { tion-flux } \\
\text { density }{ }^{2} \text {, } \\
\text { in } \mathrm{m} / \mathrm{yr}\end{array}$ & $\begin{array}{l}\text { Chloride- } \\
\text { mass flux } \\
\text { across land } \\
\text { surface }{ }^{2} \\
\text { in } \mathbf{g} / \mathrm{m}^{2} \mathrm{yr}\end{array}$ & $\begin{array}{l}\text { Interval } \\
\text { used for } \\
\text { calculation, } \\
\text { in meters }\end{array}$ & $\begin{array}{l}\text { Recharge, } \\
\text { in percent- } \\
\text { age of } \\
\text { infiltration }\end{array}$ & $\begin{array}{l}\text { Chloride } \\
\text { concen- } \\
\text { tration in } \\
\text { interval, } \\
\text { in } \mathbf{g} / \mathbf{m}^{3}\end{array}$ & $\begin{array}{l}\text { Recharge-flux } \\
\text { density from } \\
\text { chloride mass- } \\
\text { balance, } \\
\text { in } \mathrm{m} / \mathrm{yr}\end{array}$ & $\begin{array}{l}\text { Average } \\
\text { water } \\
\text { content in } \\
\text { interval, } \\
\text { in } \mathrm{m}^{3} / \mathrm{m}^{3}\end{array}$ & $\begin{array}{l}\text { Estimated } \\
\text { time to } \\
\text { reach water } \\
\text { table } \\
\text { in years }\end{array}$ & $\begin{array}{l}\text { Recharge- } \\
\text { flux density } \\
\text { from tracer- } \\
\text { velocity }{ }^{2} \text {, } \\
\text { in } \mathrm{m} / \mathrm{yr}\end{array}$ \\
\hline \multicolumn{10}{|c|}{ Amargosa River channel (ephemeral flow, normally dry) } \\
\hline $\mathrm{C} 1$ & 0.75 & 11 & $1.1-14.4$ & 12 & 121 & 0.09 & 0.21 & 225 & $\mathrm{NA}^{4}$ \\
\hline $\mathrm{C} 2$ & 0.24 & 4 & $1.6-9.5$ & 15 & 97 & 0.04 & 0.18 & 470 & 0.07 \\
\hline \multicolumn{10}{|c|}{ Undisturbed native vegetation (interfluvial surfaces) } \\
\hline ADRS & 0.11 & 0.06 & $-^{5}$ & - & - & - & - & - & - \\
\hline AFNV & 0.11 & 0.06 & - & - & - & - & - & - & - \\
\hline \multicolumn{10}{|c|}{ Field 1 (7.7-year old irrigated field, used continuously) } \\
\hline $\mathrm{AF}-1 \mathrm{~A}$ & 2.1 & 14 & $1.5-5.9$ & 6 & 116 & 0.12 & 0.21 & 60 & $0.19^{6}$ \\
\hline $\mathrm{AF}-1 \mathrm{~B}$ & 2.1 & 14 & $1.2-14.0$ & 10 & 69 & 0.21 & 0.20 & 34 & $0.30^{6}$ \\
\hline \multicolumn{10}{|c|}{ Field 2 (irrigated field, used intermittently since the 1960s) } \\
\hline $\mathrm{AF}-2 \mathrm{~A}$ & 2.1 & 14 & $0.8-9.8$ & 22 & 30 & 0.47 & 0.16 & 12 & $0.17^{7}$ \\
\hline $\mathrm{AF}-2 \mathrm{~B}$ & 2.1 & 14 & $1.2-9.7$ & 9 & 71 & 0.20 & 0.16 & 30 & $0.13^{7}$ \\
\hline \multicolumn{10}{|c|}{ Field 3 (irrigated field, used continuously since the 1960s) } \\
\hline $\mathrm{AF}-3 \mathrm{~A}$ & 2.8 & 19 & $0.8-9.9$ & 14 & 48 & 0.44 & 0.17 & 14 & $\mathrm{NA}^{4}$ \\
\hline $\mathrm{AF}-3 \mathrm{~B}$ & 2.8 & 19 & $0.8-16.0$ & 17 & 42 & 0.50 & 0.22 & 15 & $\mathrm{NA}^{4}$ \\
\hline
\end{tabular}

${ }^{1}$ See table 2 and figure 9 for locations.

${ }^{2}$ Surface fluxes and chloride concentrations from Stonestrom, Prudic, and others (2003).

${ }^{3}$ Water table is about 35 meters deep beneath the Amargosa farms (AF) sites and 100 meters deep beneath the Amargosa River channel (C1 and C2) sites. Travel times assume one-dimensional vertical flow.

${ }^{4} \mathrm{NA}$, not available.

5 -, not applicable.

${ }^{6}$ From velocity of chloride peak.

${ }^{7}$ From velocity of nitrate peak. 
February 23-24, 1998 flow event. Comparisons of the channel thermographs with control thermographs outside the active channel at PS-1, PS-5, and PS-6E allowed non-flow events to be differentiated from flow events, even for low-flow conditions (fig. 11; Constantz and others, 2001).

Figures 12 and 13 show typical thermographs for drychannel and flowing conditions, repectively. In Beatty Wash, just upstream of its confluence with the Amargosa River, flow began at about 10:00 a.m. on February 23 and ended 17 hours later. The duration was extended by snowmelt from higher elevations (Tanko and Glancy, 1999). The initiation of flow is indicated by the change from a diurnally varying temperature to a nearly constant temperature. The cessation of flow is indicated by reappearance of the diurnal signal. Flow exhumed the temperature logger, increasing the diurnal range. Twelve hours after arriving at Beatty Wash, flow arrived at the PS-1 site, 9.1 kilometers downstream. Flow at PS-1 lasted about 8 hours. Flow arrived at PS-6E at about 3:00 a.m. on February 24, 31.2 kilometers downstream from Beatty Wash, and lasted about 3 hours.

Flows in February 1998 occurred during long periods of overcast skies, reducing the magnitude of thermal signals. Summer flows were marked by larger signals. Figure 14 shows thermographs indicating the July 1999 flows. The contrast between ambient streambed temperatures and ephemeral streamflow averages about $10^{\circ} \mathrm{C}$. Flows are more easily identified in summer than in winter, because of greater contrasts between the temperature of streamflow and channel sediments prior to flow.

Brief periods of flow near the basin inlet also were indicated by thermocouple-nest data corresponding to the JanuaryFebruary 2001 flow events. Times of peak flows as recorded by the Beatty gage (fig. 5) are indicated by arrows (fig. 15). Downward advection of heat by infiltrating water compressed the ambient range in temperatures and carried diurnal fluctuations deep into the profile. The thermal anomalies from brief periods of ephemeral flow appear as perturbations on the seasonal turnover of the temperature gradient (fig. 15).

Nearly all of the thermal records are for dry-channel conditions, but even these show systematic variations consistent with the relative frequency of flow. Average channel temperatures increased with distance from the basin inlet. The increase is greater than the $0.0098^{\circ} \mathrm{C}$ per meter of altitude decrease expected on the basis of weather-station data, suggesting cooling from greater quantities of infiltration and evaporation closer to the basin inlet. Deep temperature profiles support this suggestion. Annual temperature envelopes at the two channel locations ( $\mathrm{C} 1$ and $\mathrm{C} 2$ ) and at the ADRS (between $\mathrm{C} 1$ and $\mathrm{C} 2$ ) show that the highest temperatures are outside the channel, where deep percolation and evaporated streamflow amounts are negligible. The coolest conditions are at the upstream channel location, where streamflow is most frequent and deep percolation amounts highest (fig. 16). The temperature difference between upstream and downstream locations is about 20 percent greater than can be accounted by the difference in elevation. The difference between the warmest temperatures, at the ADRS, and coolest temperatures, at the downstream channel site, is opposite that expected from altitude.

The difference in annual volume of infiltrated water between upstream and downstream channel locations is about $1.5 \mathrm{~m}^{3}$ per meter of channel length. Assuming reasonable values for sediment density $\left(2.0 \times 10^{6} \mathrm{gram} \mathrm{m}^{-3}\right)$ and heat capacity $\left(2.2 \times 10^{6}\right.$ joule $\left.\mathrm{m}^{-3}{ }^{\circ} \mathrm{C}^{-1}\right)$ at ambient water content, and given the large latent heat of evaporation $\left(2.27 \times 10^{9}\right.$ joule $\mathrm{m}^{-3}$ ), the cooling power of infiltrated water is more than sufficient to account for the difference in temperatures. If half of the infiltrated volume later evaporated, channel sediment 3 meters wide (the width of the active channel) by 20 meters deep would cool about $13^{\circ} \mathrm{C}$ per year if all heat came from cooling of the sediment. Depth and degrees of cooling are inversely proportional. The actual cooling is far less than this because of heat exchange with surrounding sediments. Nevertheless, average temperatures reflect differences consistent with infiltration and recharge regimes.

\section{Recharge Estimates from Potential and Environmental-Tracer Profiles}

Profiles of water potential, water content, and solute concentrations beneath irrigated fields, undisturbed native vegetation, and the normally dry channel of the Amargosa River also reflect the contrast in recharge regimes. Examples of water-potential profiles beneath the channel, native vegetation, and irrigated fields are shown in figure 17. Water potentials generally are low beneath native vegetation, with potentials lower (more negative) than -5 megapascals (MPa) in most of the profile. The profile beneath native vegetation in the Amargosa Farms area is similar to the profile beneath native vegetation at the ADRS, where calculated deeppercolation fluxes are zero to slightly upward (Walvoord and others, 2004). Gradients of temperature, water potential, and stable isotopes beneath undisturbed native vegetation at the ADRS indicate a net upward flow of heat and water throughout the profile (Stonestrom and others, 1999). Models of heat and water movement indicate that these profiles are not in equilibrium with current climatic conditions - instead, they are slowly drying in response to the change from pluvial to arid conditions that occurred in the late Pleistocene (Walvoord and others, 2004).

In contrast, to the profiles beneath native vegetation, water potentials beneath irrigated fields and the Amargosa River channel indicate net downward movement of water, with potentials close to zero in most of the profile (fig. 17). Water potentials are more variable beneath a more recently converted field than beneath fields converted in the 1960s, reflecting the shorter duration of irrigation return flow. High, nearly uniform water potentials beneath the older fields and channel sites indicate long-established deep percolation in which the sediments have water potentials associated with approximately steady-state downward flow (Stonestrom, Prudic, and others, 2003). 

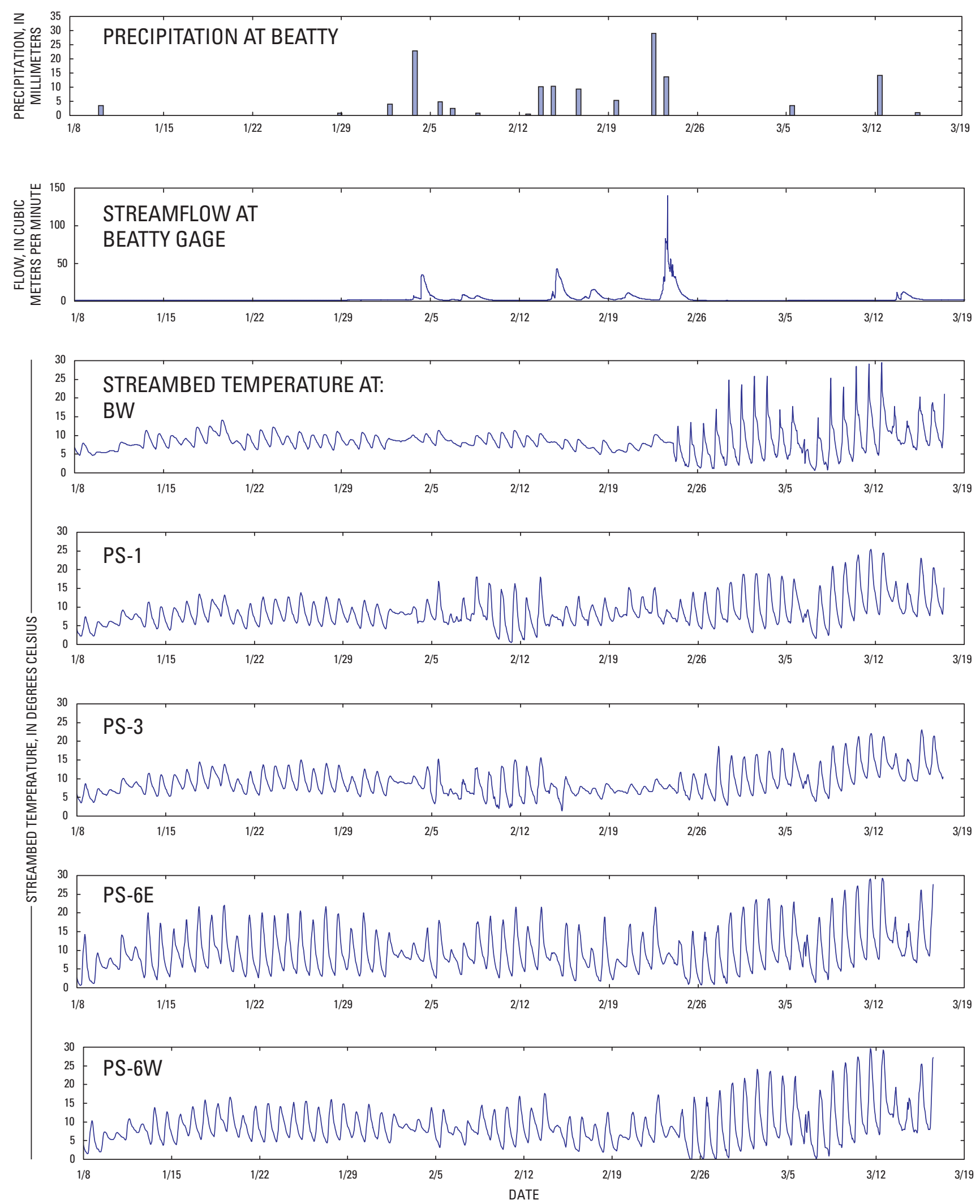

Figure 10. Precipitation and streamflow at Beatty, Nev., and streambed temperatures at selected sites in Beatty Wash (BW) and the Amargosa River channel, January 8 through March 17, 1998. Site locations are shown on figure 9. 

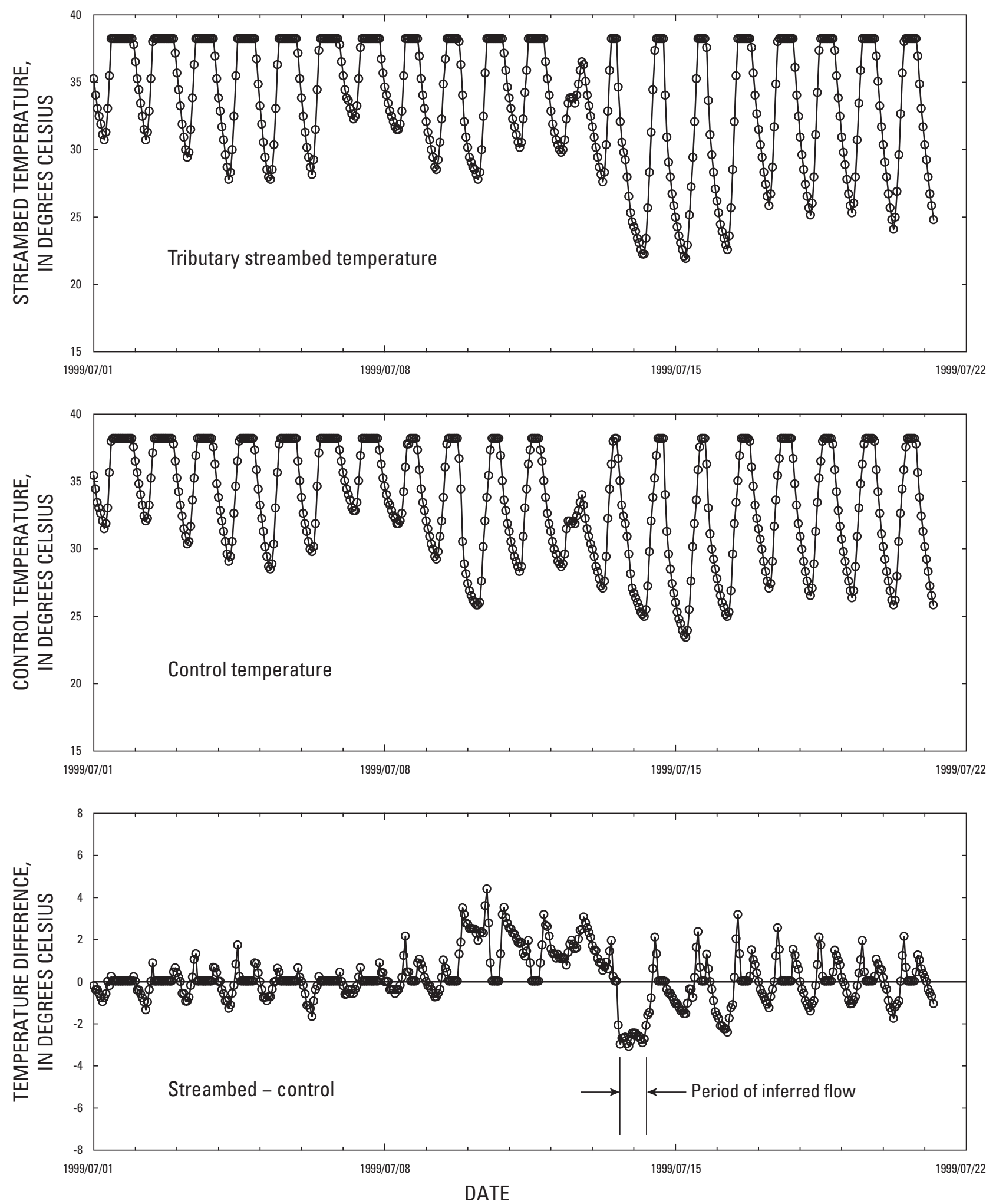

Figure 11. Timing of sheet flow in an unnamed minor tributary to the Amargosa River (site PS-6T, figure 9) is indicated by a drop in the streambed temperature as compared to the control temperature. Temperatures higher than the upper limit of the temperature logger are truncated at $38^{\circ} \mathrm{C}$. 

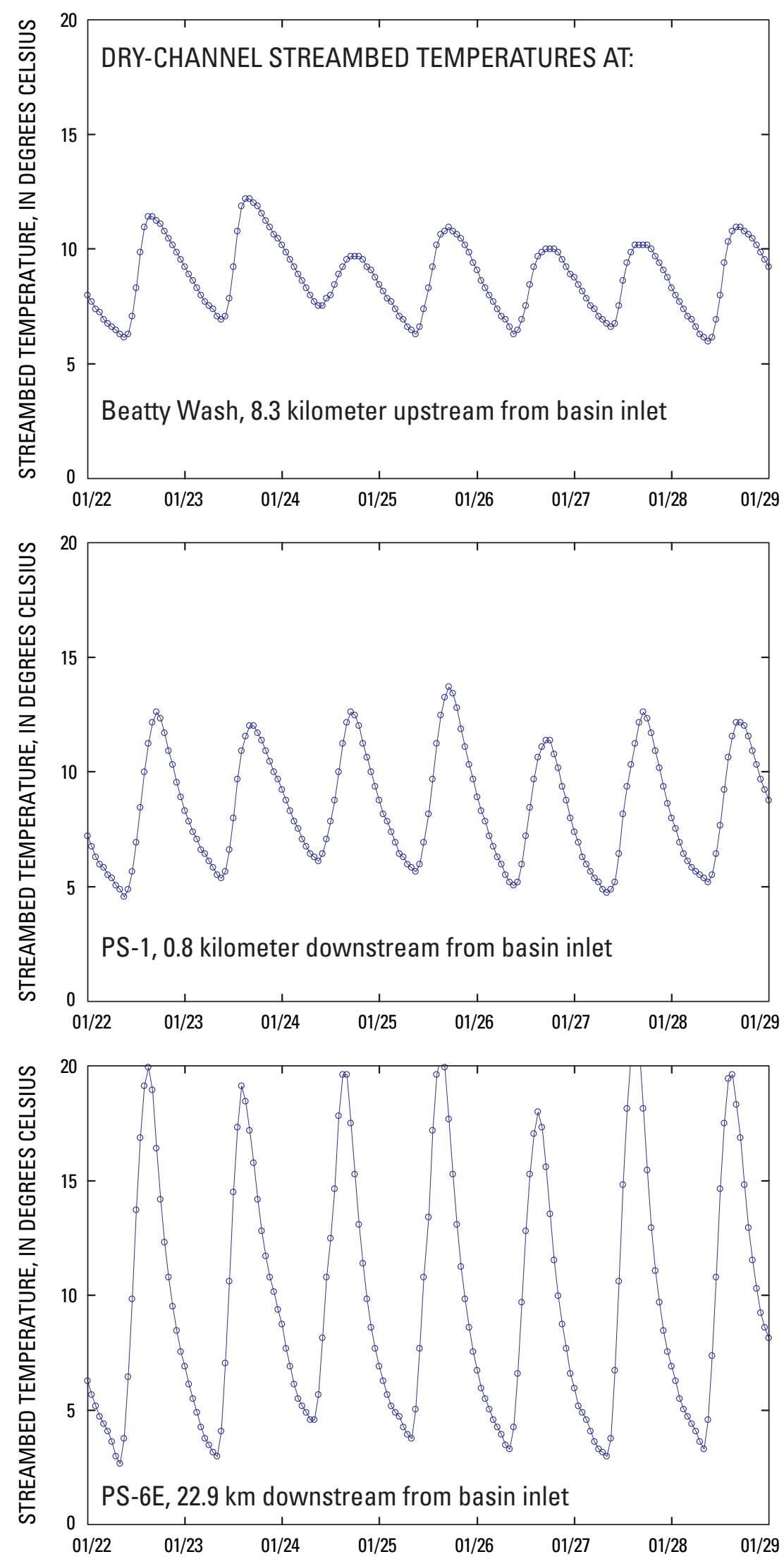

Figure 12. Example streambed temperatures during dry conditions, Amargosa Desert study area, January 22 through 28, 1998. Site locations are shown on figure 9. 

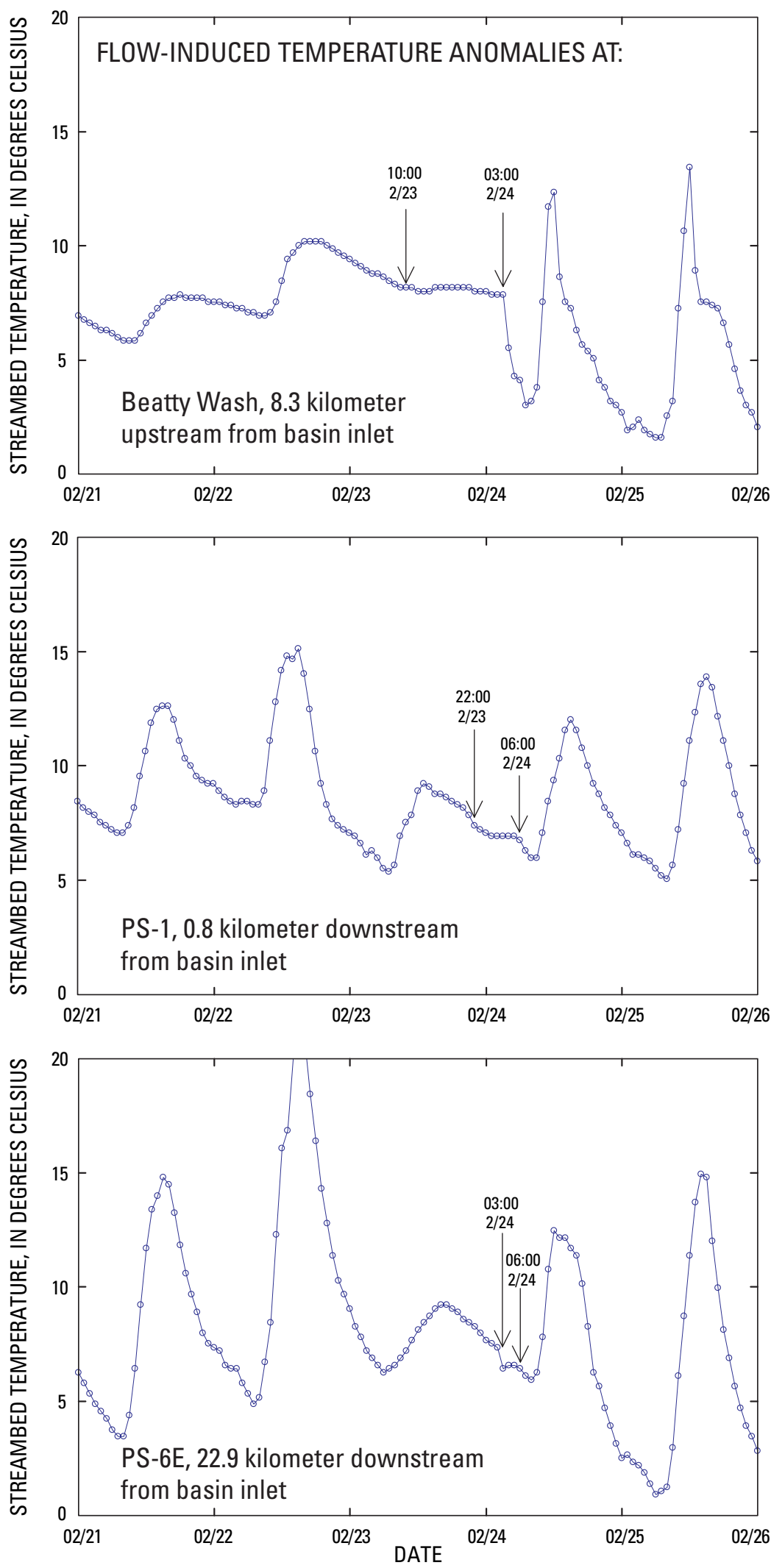

Figure 13. Example streambed temperatures during period with ephemeral flow, Amargosa Desert study area, February 21 through 25, 1998. Arrows indicate thermal anomalies interpreted as initiation and cessation of flow. Site locations are shown on figure 9 . 

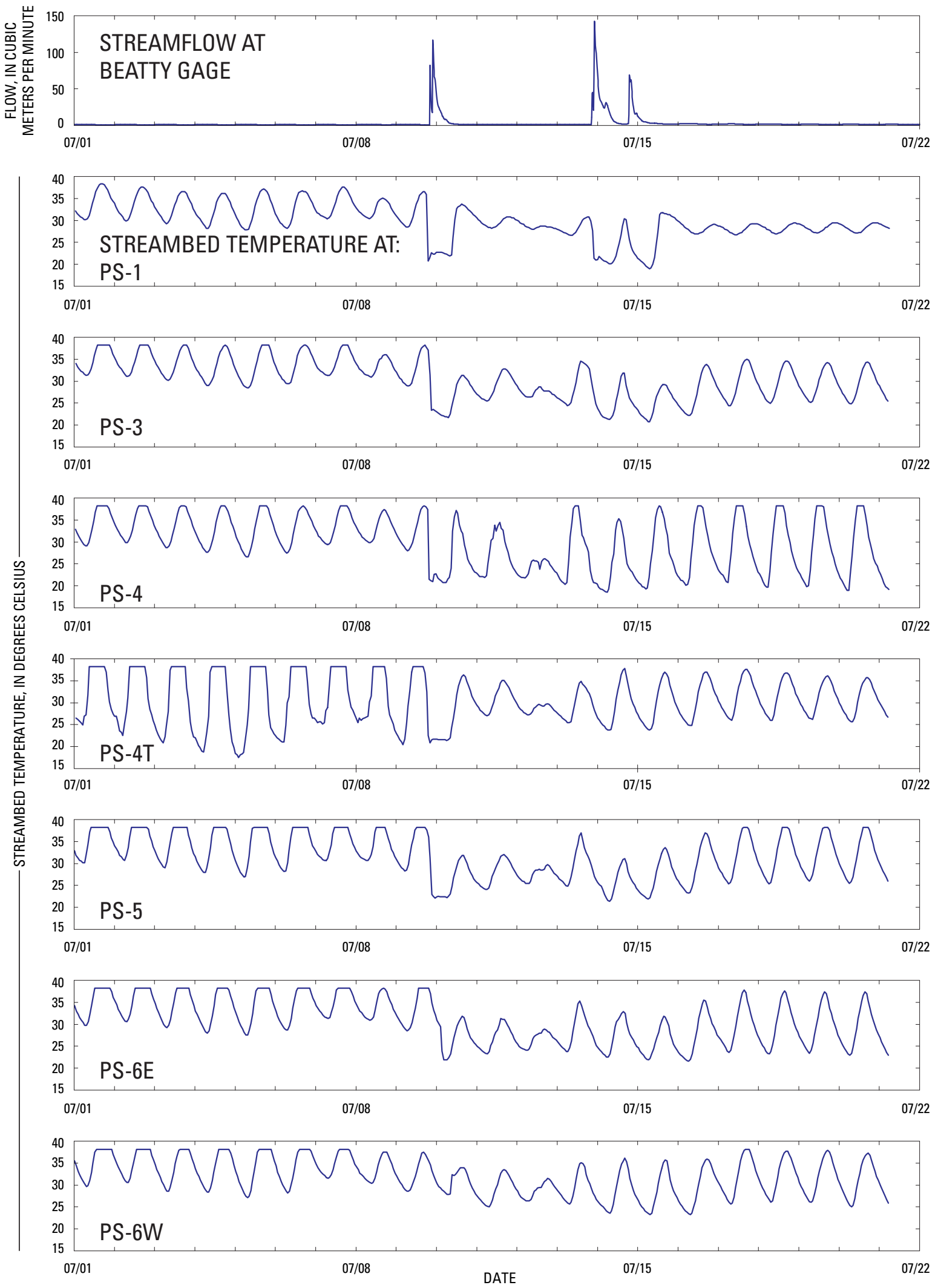

Figure 14. Amargosa River streamflow at Beatty, Nev., and streambed temperatures downstream, July 1 through 21, 1999. Temperatures higher than the upper limit of the temperature logger are truncated at $38^{\circ} \mathrm{C}$. Figure 9 shows site locations. 


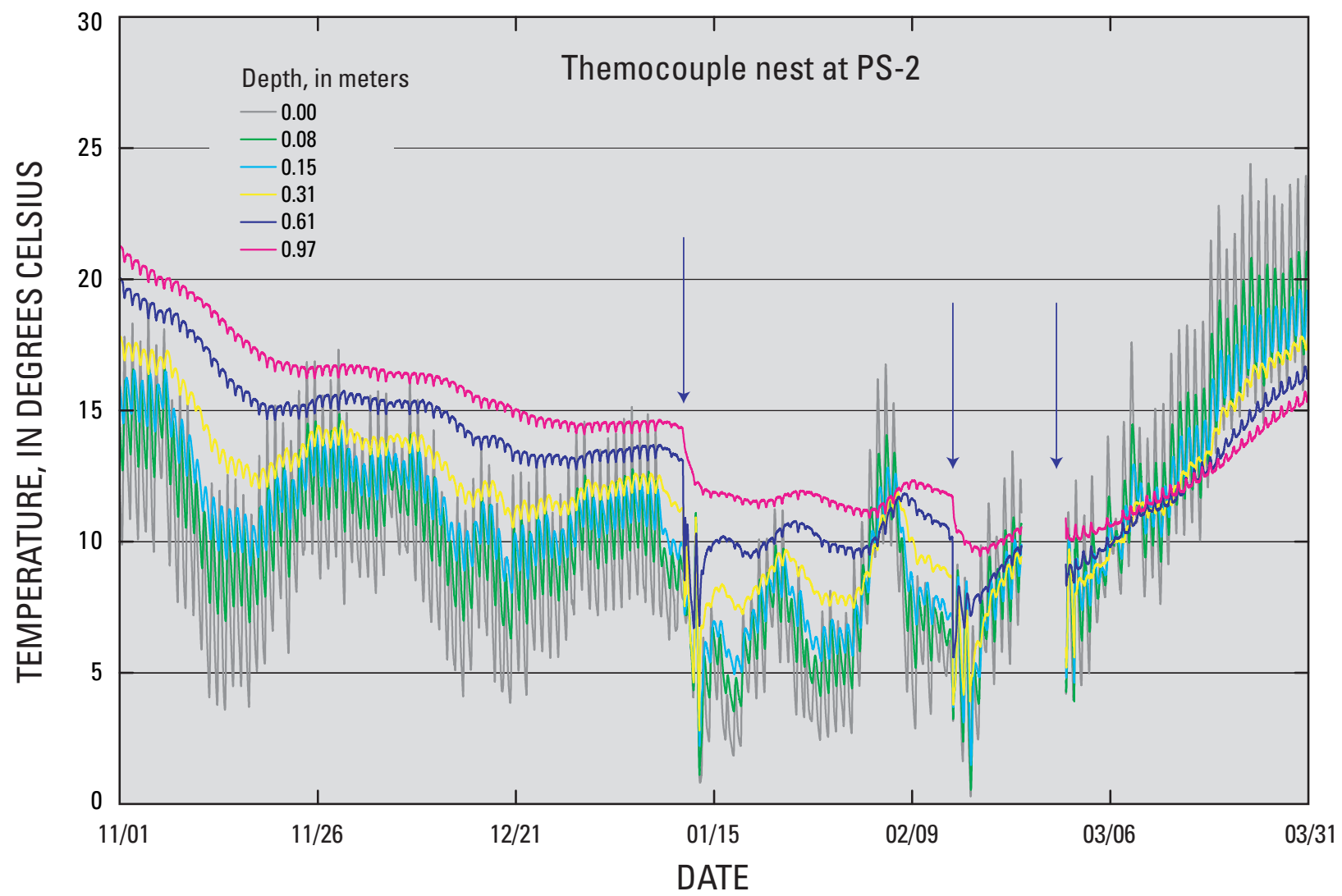

Figure 15. Channel temperatures at six depths near PS-2, 2.4 kilometers from the basin inlet, Amargosa Desert study area, November 2000 through March 2001. Arrows show times of peak flow at Beatty (fig. 5). Gap in record is due to loss of power to data logger.

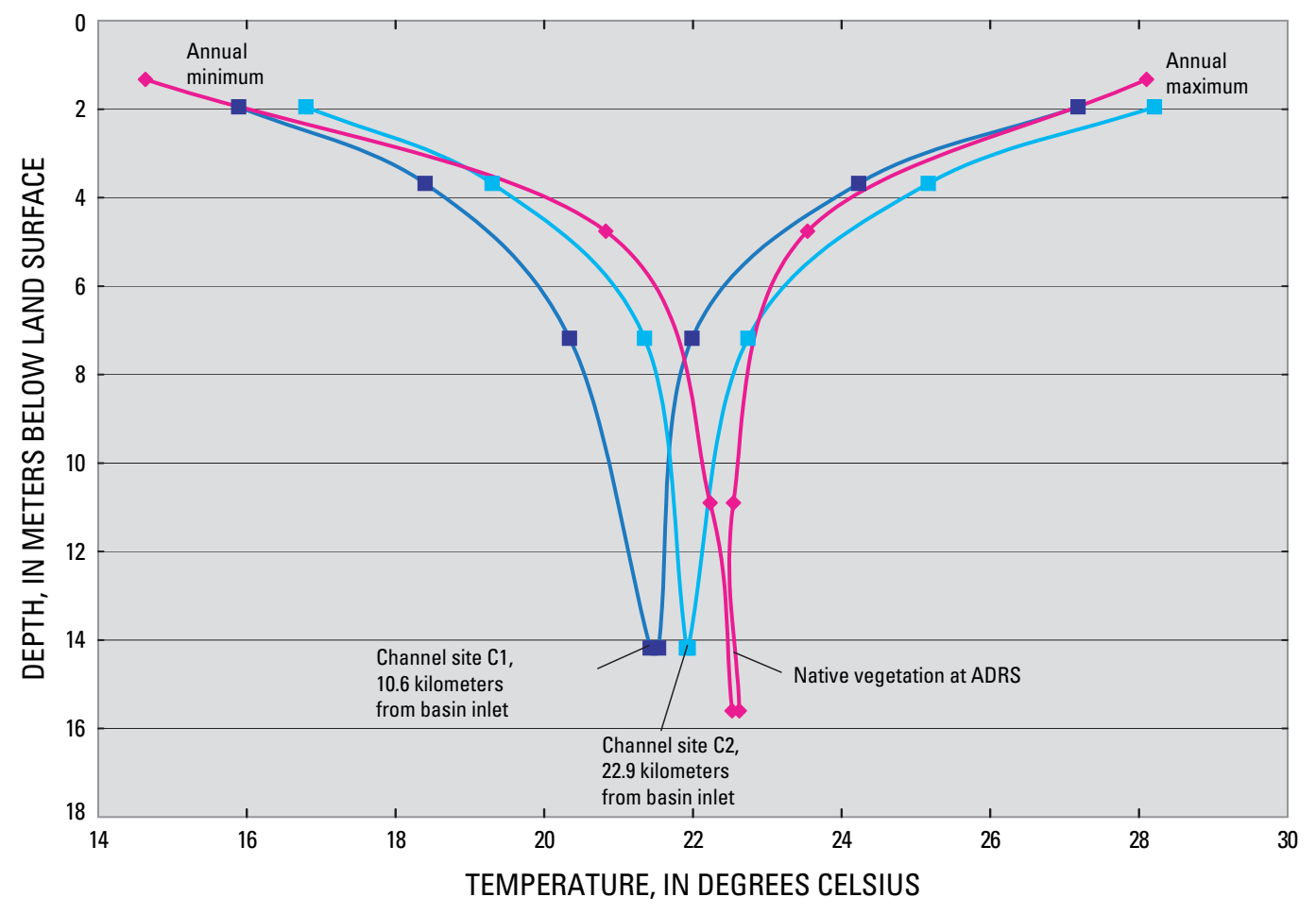

Figure 16. Annual temperature envelopes beneath channel site $\mathrm{C} 1$ and $\mathrm{C} 2,10.6$ and $22.9 \mathrm{~km}$ downstream from the Amargosa Desert Basin inlet, and beneath native vegetation at the Amargosa Desert Research Site (ADRS), halfway between $\mathrm{C} 1$ and $\mathrm{C} 2$. Figure 9 shows site locations. 


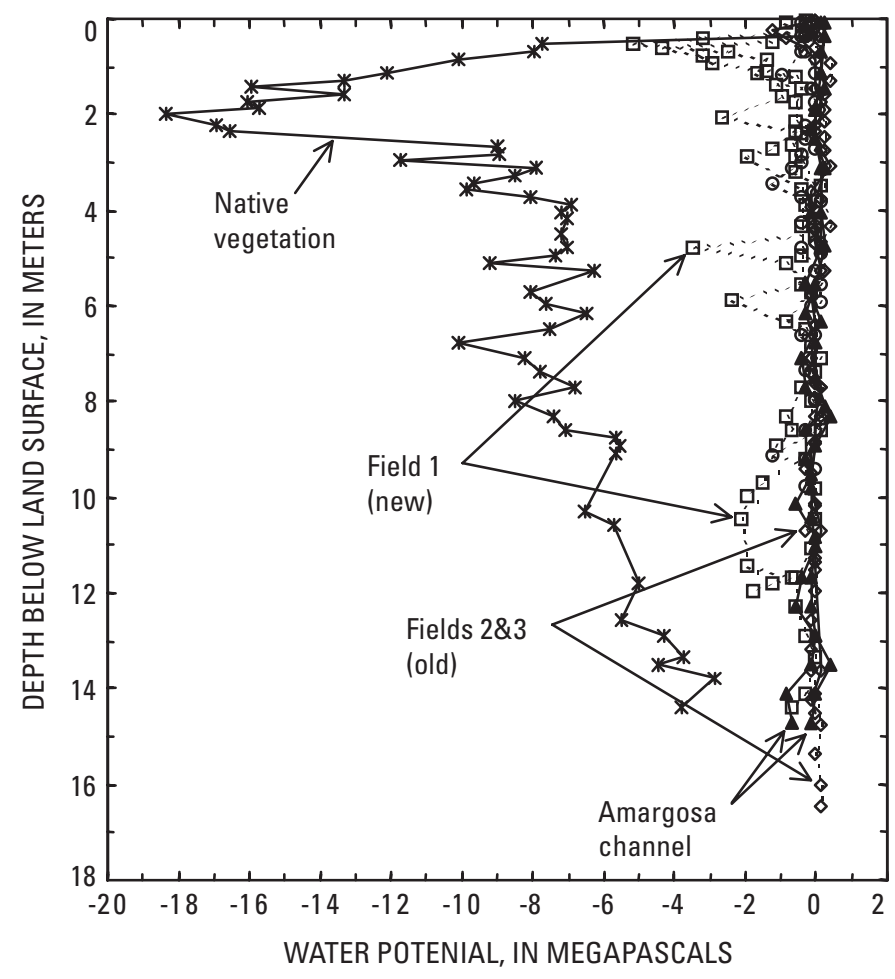

Figure 17. Unsaturated-zone water potential profiles beneath native vegetation and irrigated fields in the Amargosa Farms area, and the normally dry Amargosa River channel. Storms wetted surface sediments prior to sampling in February 2001, producing near-zero water potentials at shallow depths at all sites. Water potentials beneath the Amargosa River channel (C1 and C1, triangles) and older fields ( 2 and 3 , circles and diamonds) are close to zero throughout the profile. Water potentials beneath the new field (open squares) are near zero but more variable than beneath the older field. From Stonestrom and others (2004).

Chloride and nitrate profiles at all undisturbed nativevegetation sites are similar, with large increases in concentration (bulges) just below the root zone (fig. 18). Bulges in the concentrations of atmospherically derived salts are common beneath desert plants (Phillips, 1994; Tyler and others, 1996; Hartsough and others, 2001). Initiation of chloride accumulation dates back to the major change in climate from the cool and wet (pluvial) conditions prevailing during the late Pleistocene to the arid-thermic conditions prevailing today (Walvoord and others, 2004). Increasing aridity led to the succession of xerophytes efficient at scavenging moisture, resulting in accumulation of atmospherically deposited salts just beneath the root zone (Walvoord, Plummer, and others, 2002; Walvoord, Phillips, and others, 2002). The change from pluvial to dry conditions in the Amargosa Desert Basin may have started as early as 20,000 years ago on the basis of vegetation changes in the area (Spaulding, 1985), paleoclimate modeling (Spaulding and Graumlich, 1986), and an abrupt decline in ground-water level recorded at Devils Hole (fig. 1; Szabo et al., 1994).

Assuming that the profiles beneath field 1 were initially like those beneath undisturbed native vegetation, chloride peaks at depths of about 9 and $13 \mathrm{~m}$ demonstrate that deep percolation from irrigation return flow is moving previously accumulated chloride downward from just below the root zone (fig. 18A). Eight years of irrigation is insufficient to flush accumulated salts from the sampled profile completely. Subroot-zone nitrate profiles are similar to the chloride profiles, reinforcing this conclusion (fig. 18B).

Chloride concentrations beneath the root zone of field 2 are uniformly low, indicating that deeply percolating irrigation water has flushed the presumed preexisting bulge completely from the measured profile (fig. 18A). Sub-root-zone nitrate concentrations are much lower than chloride concentrations at most depths, except for one interval in each profile where nitrate concentrations are consistently at least twice the chloride concentrations. These well-defined nitrate peaks occur in the 6.9-8.3-m interval at one borehole and in the 8.3-9.8-m interval at the other (fig. 18B). The peaks most likely represent heavy application of liquid fertilizer in 1992, when the field was returned to production.

Profiles of chloride and nitrate beneath the Amargosa River channel are similar to those beneath the irrigated fields in that they lack salt accumulations near land surface (fig 18). Chloride and nitrate concentrations at the upstream site are low throughout the profile at all depths greater than 1 $\mathrm{m}$. Concentrations at the downstream site rise sharply in the 10 to 14-m depth interval. This abrupt rise suggests downward displacement of a previously formed salt bulge, similar to the downward-advected bulge at field 1 .

The active channel at $\mathrm{C} 2$ appears to have moved to its current position during the record flood of 1969 (fig. 6). Aerial photographs taken before 1969 show the channel at $\mathrm{C} 2$ about 0.5 kilometer east of its present location and the channel at $\mathrm{C} 1$ in its present location. Photos taken after 1969 show the channel in its present location at both sites. As at field 1 , the duration of deep percolation at $\mathrm{C} 2$ has been insufficient to move previously accumulated salts completely from the sampled profile.

\section{General Patterns of Deep Percolation and Ground-Water Recharge}

The slope of the relation between cumulative chloride and cumulative water represents a depth-integrated pore-water chloride concentration. A linear relation that passes through the origin is consistent with the hypothesis that chloride fluxes at depth are in approximate equilibrium with time-averaged fluxes across the land surface, in accordance with the assumptions of the chloride mass-balance method (Stonestrom, Prudic and others, 2003).

Almost all of the profiles beneath the irrigated fields and channel sites show evidence of approximately steady-state 
$A$

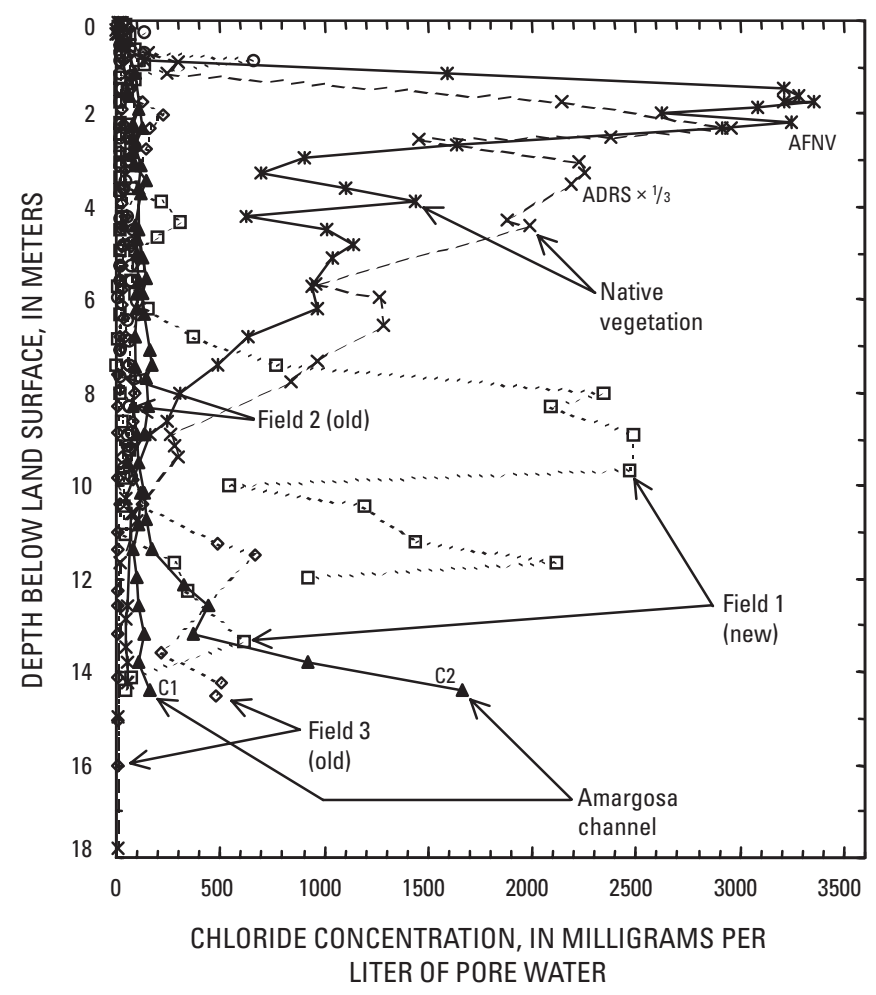

$B$

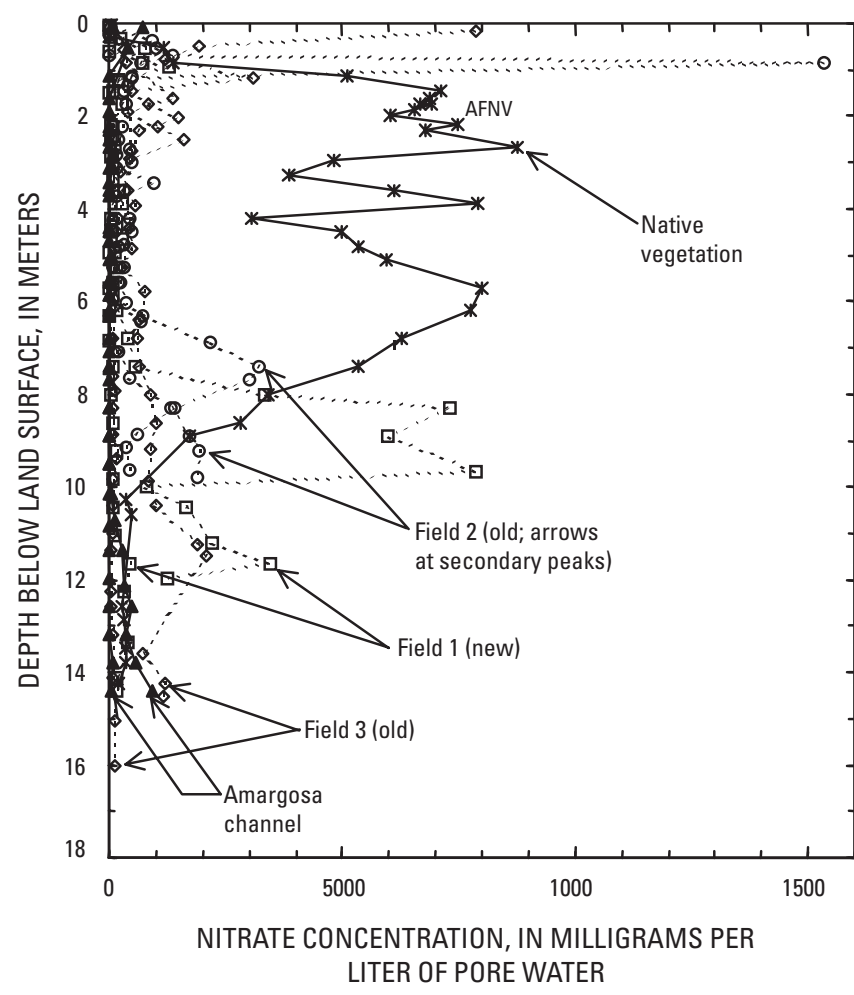

Figure 18. Profiles of anion concentrations in pore water beneath native vegetation, irrigated fields, and the Amargosa River channel, in the Amargosa Desert study area. $A$, chloride-concentration profiles; $B$, nitrate-concentration profiles. The ADRS is the Amargosa Desert Research Site (fig. 9). From Stonestrom and others (2004).

deep percolation, that is, simple linear relations that extrapolate towards the origin (fig. 19). Deviations in slope near the origin reflect the effects of unfiltered variations in surface forcing from meteorological conditions in the immediate past. The new field and the downstream channel site show concave upward departures from linearity at depth. As already discussed, these reflect previously formed shallow salt accumulations moving downward through the profile due to the recent onset of deep percolation.

In contrast to the sites indicating steady deep percolation, relations between cumulative chloride and cumulative water content beneath native vegetation are characterized by steep segments at shallow depths (close to the origin) that do not extrapolate through the origin, followed by sharp inflections to relatively low slopes beneath the root zone (far from the origin; fig. 19). These patterns indicate a lack of chloride throughput due to lack of water movement between the bottom of the root zone and the water table. The non-linear relations show that chloride fluxes at depth are not in equilibrium with fluxes across the land surface, violating a key assumption of the chloride mass-balance approach (Scanlon, 2000).

Multiyear observations at the ADRS indicate that precipitation on areas of undisturbed native vegetation penetrates to depths of less than one meter before returning to the atmosphere (Fischer, 1992; Andraski, 1997). Isotopic data from the
ADRS (Stonestrom and others, 1999) and the Nevada Test Site (Tyler and others, 1996) support the conclusion of negligible recharging fluxes under current climatic conditions and rule out dilution of deep pore water by preferential flow of recent infiltration. Instead, low chloride concentrations in pore water beneath shallow chloride and nitrate bulges represent relict recharge from pluvial periods. Modeling studies of coupled heat and water movement indicate that the net movement of water (liquid plus vapor) is upwards in an increasingly deep region beneath the root zone under current climatic conditions (Walvoord and others, 2004).

\section{Estimates of Recharging Fluxes Beneath Irrigated Fields}

Table 5 shows chloride mass-balance estimates of recharging fluxes beneath irrigated fields. The table includes the depth intervals and average pore-water chloride concentrations corresponding to the linear portions of the cumulativewater versus cumulative-chloride curve for which the chloride mass-balance method applies (fig. 19).

The chloride-mass balance estimates of deep percolation for field 1 are 0.12 and $0.21 \mathrm{~m} \mathrm{yr}^{-1}$. Downward displacement of the salt bulge following onset of irrigation in field 1 


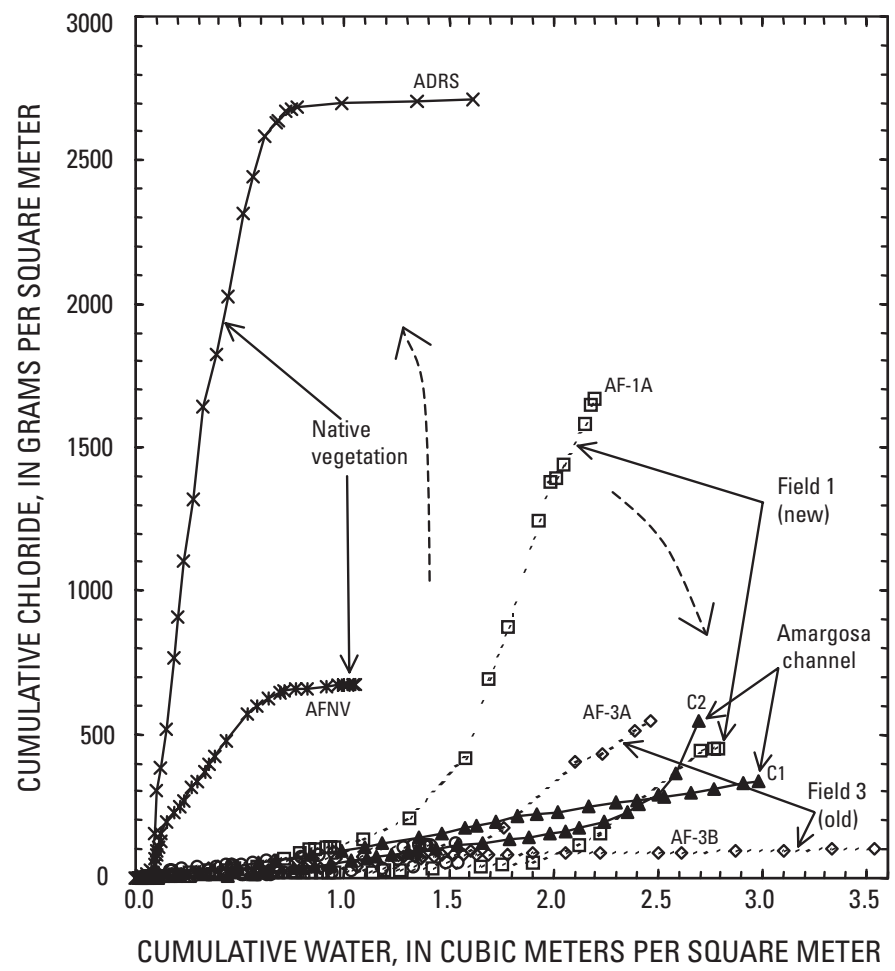

Figure 19. Cumulative mass of chloride versus cumulative volume of water beneath undisturbed native vegetation, irrigated fields, and the Amargosa River channel, in the Amargosa Desert study area. Slopes of the curves represent pore-water concentrations of chloride, which are inversely proportional to recharge rates for steady-state conditions (linear relations). $\mathrm{AF}-3 \mathrm{~B}$ is in the interior of the field; $3 \mathrm{~A}$ is on the perimeter. Dashed arrows indicate time trajectories of profile evolution under current climatic and land-use conditions. The ADRS is the Amargosa Desert Research Site (fig. 9). From Stonestrom and others (2004).

provides a largely independent estimate of deep percolation. Assuming that the center of mass of the chloride moved from about $1.8 \mathrm{~m}$ (the observed depth under native vegetation) to 8.9 and $13 \mathrm{~m}$ in 7.7 years, the macroscopic velocities of the bulge are 0.9 and $1.5 \mathrm{~m} \mathrm{yr}^{-1}$, respectively. Multiplying by the average water content gives deep-percolation estimates of 0.19 and $0.30 \mathrm{~m} \mathrm{yr}^{-1}$ (table 5). These rates are about 50 percent higher than the chloride mass-balance estimates, reflecting the uncertainty of the estimates (Stonestrom, Prudic and others, 2003). Similar variations in deep-percolation rates characterized a sandy agricultural field in a semiarid region in the western Murray Basin, South Australia (Cook and others, 1989).

The chloride mass-balance estimates of deep percolation for field 2 are 0.20 and $0.47 \mathrm{~m} \mathrm{yr}^{-1}$. Travel-time estimates based on the nitrate peak are 0.13 and $0.17 \mathrm{~m} \mathrm{yr}^{-1}$ (table 5). These estimates are based on the assumption that the deep nitrate peaks represent surface application of liquid fertilizer in 1992, when field 2 went back into production after being fallow for nine years. The lower nitrate-based values suggest retardation of nitrate relative to chloride in the root zone (Smith, Doyle, and others, 1997). Chloride mass-balance estimates of deep percolation beneath field 3 are 0.44 and 0.50 $\mathrm{m} \mathrm{yr}^{-1}$ (table 5). The percentage of irrigation water returning to the water table is simply the ratio of chloride concentration in irrigation water to that in deep pore water. The average estimated percentage of return flow is 8 percent for field 1,15 percent for field 2, and 16 percent for field 3 . Differences correlated with cultivation histories. Field 3 had the highest rates of irrigation and the highest percentage of return flow.

The depth to ground water beneath the irrigated fields is about $35 \mathrm{~m}$ (Kilroy, 1991). Assuming vertical, one-dimensional flow, the estimated time for irrigation return flow to reach the water table is 12-30 years beneath fields 2 and 3, and 34-60 years beneath field 1 (table 5). This pattern is consistent with asymptotically decreasing divergence of infiltrating water through time following the onset of irrigation in an initially dry profile (Philip, 1983).

\section{Estimates of Recharging Fluxes Beneath the Amargosa River Channel}

Chloride mass-balance estimates of deep percolation for the upstream-channel site $(\mathrm{C} 1)$ used the entire profile below $1.1 \mathrm{~m}$, the depth below which the cumulative chloride-cumulative pore water relationship indicated approximately steady conditions (table 5). Estimates for the downstream site excluded concentrations deeper than 9.5 $\mathrm{m}$. Elevated chloride beneath this depth evidently represents a near-surface accumulation that began moving downward when the active channel shifted to its current location, as indicated by aerial photographs. Chloride mass-balance deep-percolation rates were $0.09 \mathrm{~m} \mathrm{yr}^{-1}$ at the upstream site and $0.04 \mathrm{~m} \mathrm{yr}^{-1}$ at the downstream site. These rates exceed estimated sub-root zone liquid and vapor fluxes at the ADRS by several orders of magnitude (Walvoord and others, 2004). Thus, virtually all deep percolation beneath the channel becomes ground-water recharge.

Assuming that the chloride bulge at $\mathrm{C} 2$ moved downward from 1.8 to $14.4 \mathrm{~m}$ in the 32 years between the flood of 1969 and sampling in 2001, the macroscopic velocity is $0.39 \mathrm{~m} \mathrm{yr}^{-1}$. The travel-time estimate of deep percolation is the product of the macroscopic velocity times the volumetric water content of 0.18 , or $0.07 \mathrm{~m} \mathrm{yr}^{-1}$ (table 5). This value is in approximate agreement with the chloride mass-balance rate of $0.04 \mathrm{~m} \mathrm{yr}^{-1}$.

The percentage of channel infiltration that becomes deep percolation is about 12 percent for the upstream site and about 15 percent for the downstream site (table 5). Multiplying by the average annual streamflow volume of $3.0 \mathrm{Mm}^{3} \mathrm{yr}^{-1}$ (table 3 ), the amount of ground-water recharge from channel infiltration is about $0.4 \mathrm{Mm}^{3} \mathrm{yr}^{-1}$.

Depth to ground water beneath the Amargosa River west of the ADRS was $103 \mathrm{~m}$ in 1985 (W.D. Nichols, USGS, 
Carson City, Nev., unpub. data, 1985). Assuming the water table is about $100 \mathrm{~m}$ below the riverbed, channel infiltration takes approximately 225 years to reach the aquifer at $\mathrm{C} 1$ and 470 years at $\mathrm{C} 2$. These estimates are minimum times because the effects of lateral flow are not taken into account. While uncertainties in estimated recharge rates are considerable, the approximate agreement between travel-velocity estimates and chloride mass-balance estimates supports the general magnitude of the results.

\section{Areal Generalization by Direct-Current Resistivity Imaging}

The unsaturated-zone profiles considered above indicate that ground-water recharge is localized beneath the main channel of the Amargosa River and beneath irrigated fields, with little present-day recharge beneath native vegetation. These borehole-based results can be regionalized by remote sensing by using geomorphologic, pedologic, and vegetational mapping. To bridge the scales between remote sensing and borehole-profile analysis, the current study employed DC-resistivity imaging.

Numerical inversions of automated Schlumberger-array soundings assumed lateral homogeneity normal to the vertical slices being imaged, producing solution sets of resistivity values at several thousand points within each modeled cross section. Imaged sections were about 30 to $80 \mathrm{~m}$ deep and 1 kilometer wide. Root-mean square errors between apparent resistivities in the model inversions and field-measured apparent resistivities were about 10 percent (Stonestrom, Abraham, and others, 2003; Abraham and Lucius, 2004).

On the basis of core data from cased boreholes, inverted resistivity $(\Omega)$ values denoted three categories of alluvium: (1) low water-content coarse gravel and highly desiccated surface material, with $\rho$ greater than $200 \mathrm{Ohm}$-meters $(\Omega-\mathrm{m})$, (2) vertical regions of moist alluvium in areas of active recharge, with $\rho$ less than $20 \Omega-\mathrm{m}$, and (3) other low to low-medium water-content alluvium in areas without active recharge, with intermediate values of $\rho$ (fig. 20). The cross section beneath native vegetation near the ADRS reveals laterally extensive gravel layers that provide preferential pathways for gas transport but that are impeding layers for downward movement of water through the unsaturated zone (Mayers and others, 2005).

The DC-resistivity images indicate focusing of active recharge beneath the Amargosa River channel. At the incised channel location upstream $(\mathrm{C} 1)$, vertically elongated, lowresistivity regions indicating relatively moist sediments span the half-kilometer width of the channel (fig. 20A). A finger of low-resistivity sediment lies beneath the present low-flow channel. Pronounced low-resistivity regions are also found beneath the migrating reaches of the channel at the downstream site (C2; fig. 20B). The ADRS transect and extrachannel portions of channel transects (fig. 20C) suggest that little recharge occurs throughout most of the basin floor.

\section{Summary and Conclusions}

The current study characterized streamflow and groundwater recharge in the sparsely populated Amargosa Desert Basin of Nye County, Nev. High frequency streamflow and channeltemperature data indicated patterns of ephemeral streamflow during a 4-year period (water years 1998 through 2001). The period included the largest El Niño of the modern instrumental period, which enhanced precipitation, and two years of belowaverage precipitation.

The channel of the Amargosa River is dry more than 98 percent of the time beyond a few kilometers downstream from the basin inlet, where perennial flow supports riparian vegetation. Base flow accounted for about three quarters of the 3.0 million cubic meters $\left(\mathrm{Mm}^{3}\right)$ of discharge at the Beatty gage during the 4-year study period. The average annual flow, $0.76 \mathrm{M}$ $\mathrm{m}^{3}$ per year, was small relative to historic ground-water withdrawals for irrigation.

Streambed temperature anomalies indicated the duration and extent of storm-generated ephemeral flow into the basin. Only two flows traversed the entire reach of the Amargosa River during the 4-year study period. Durations and amount of flow declined rapidly down channel due to infiltration losses. Channel temperatures increased as infiltration and evaporation amounts decreased. Temperatures were warmest at the ADRS site, which received no flow, and lowest at the upstream channel site that received the most flow.

Unsaturated-zone profiles of water potential and environmental tracers indicate sharply contrasting recharge regimes beneath native vegetation, irrigated fields, and the normally dry channel of the Amargosa River. Recharge is negligible beneath undisturbed native vegetation covering most of the Amargosa Desert floor, where water-potential profiles indicate upward flow and atmospherically deposited salts have been accumulating more or less continuously since the end of the Pleistocene. Accumulation of salts has formed pronounced bulges just below the root zone.

Near-zero water potentials and low salt concentrations beneath irrigated fields and the Amargosa River channel indicate active deep percolation and ground-water recharge. Transit times of recharge beneath the channel are on the order of centuries. Transit times of irrigation-return flow are on the order of decades. Velocities of displaced chloride and nitrate bulges beneath a migrated channel and a newly irrigated agricultural field provide largely independent estimates of recharging fluxes that are in approximate agreement with chloride mass-balance estimates.

Chloride mass-balance calculations indicate that 12 to 15 percent of infiltrated channel water becomes recharge. The bulk of infiltrated water returns to the atmosphere. The associated evaporation cools the channel and reduces the amount of water available for ground-water recharge. The estimated amount of ground-water recharge from channel infiltration is about $0.4 \mathrm{Mm}^{3} \mathrm{yr}^{-1}$.

DC-resistivity imaging proved useful for extrapolating borehole-based values of ground-water recharge. Resistivity 


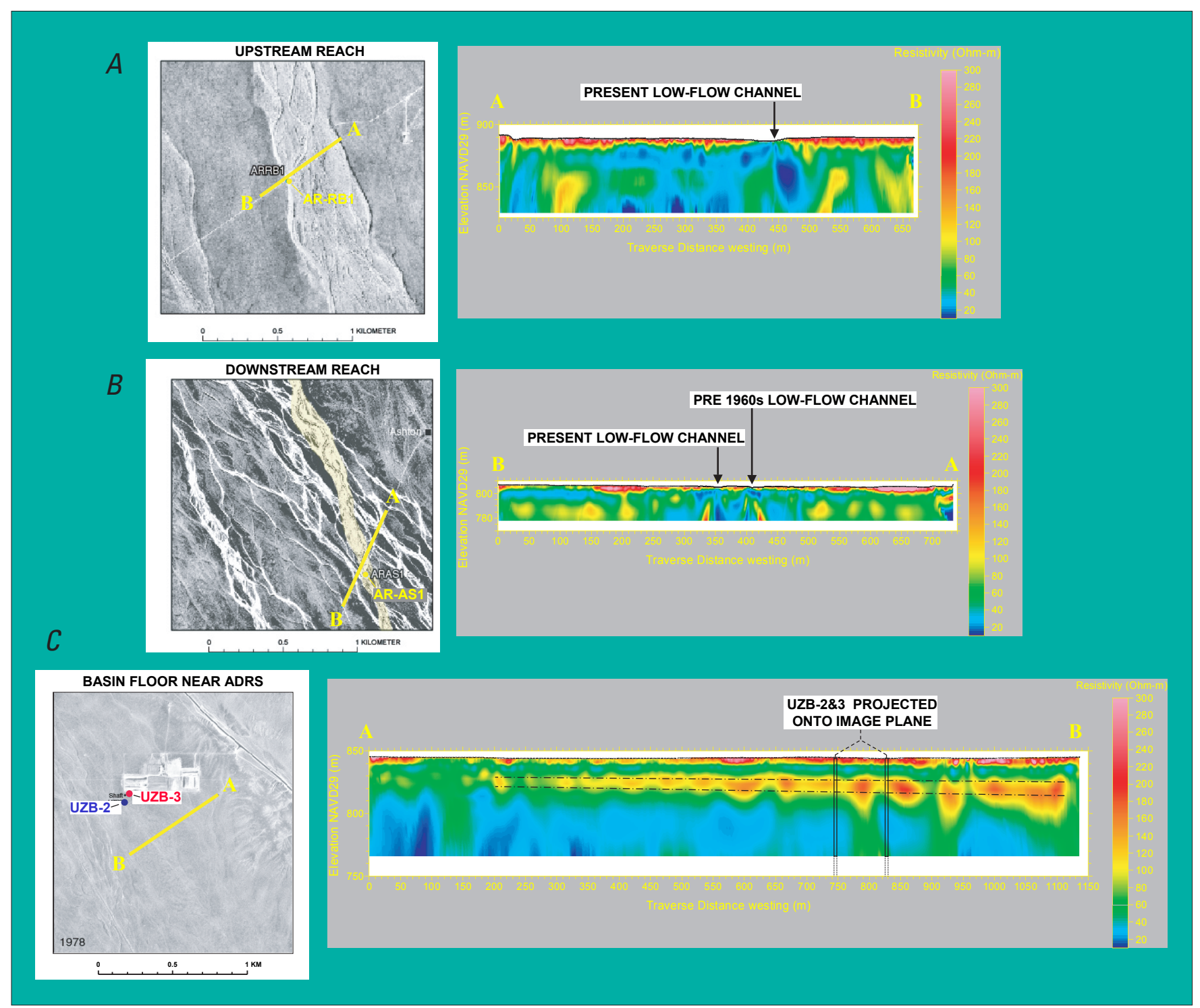

Figure 20. Direct-current resistivity transects in the Amargosa Desert study area. $A$, transect across the Amargosa River channel at site $C 1,10.6 \mathrm{~km}$ from the basin inlet; $B$, transect across the Amargosa River channel at site $C 2,22.9 \mathrm{~km}$ from the basin inlet, and; $C$, transect at the Amargosa Desert Research Site (ADRS). Figure 9 shows site locations. 
images of unsaturated-zone sediment clearly show focusing of recharge beneath the normally dry Amargosa River channel. Low-resistivities correspond to high water contents associated with active recharge from ephemeral streamflow. High-resistivities indicate coarse gravel layers and low water potentials, corresponding to regions without active ground-water recharge under current climatic conditions. Infiltration losses from the Amargosa River channel produce small amounts of recharge along the basin floor of the Amargosa Desert.

\section{References Cited}

Abraham, J.D., and Lucius, J.E., 2004, Direct current resistivity profiling to study distribution of water in the unsaturated zone near the Amargosa Desert Research Site, Nevada: U.S. Geological Survey Open-File Report 2004-1319, 16 p.

Andraski, B.J., 1997, Soil-water movement under natural-site and waste-site conditions-A multiple-year field study in the Mojave Desert, Nevada: Water Resources Research, v. 33, no. 9, p. 1901-1916.

Andraski, B.J., and Stonestrom, D.A., 1999, Overview of research on water, gas, and radionuclide transport at the Amargosa Desert Research Site, Nevada, in Morganwalp, D.W., and Buxton, H.T., eds., U.S. Geological Survey Toxic Substances Hydrology Program-Proceedings of the Technical Meeting, Charleston, South Carolina, March 8-12, 1999-Volume 3-Subsurface Contamination from Point Sources: U.S. Geological Survey Water Resources Investigations Report 99-4018C, p. 459-465.

Avon, Lizanne, and Durbin, T.J., 1994, Evaluation of the Maxey-Eakin method for estimating recharge to groundwater basins in Nevada: Water Resources Bulletin, v. 30, no. 1, p. 99-111.

Beck, D.A., and Glancy, P.A., 1995, Overview of runoff of March 11, 1995, in Fortymile Wash and Amargosa River, Southern Nevada: U.S. Geological Survey Fact Sheet FS-210-95, 4 p.

Benson, M.A., and Dalrymple, T., 1967, General field and office procedures for indirect discharge measurements: U.S. Geological Survey Techniques of Water-Resource Investigations, Book 3 Chapter A1, 30 p.

Bull, W.B., 1991, Geomorphic responses to climatic change: New York, Oxford University Press, 326 p.

Carr, M.D., and Yount, J.C., eds., 1988, Geologic and Hydrologic Investigations of a Potential Nuclear Waste Disposal Site at Yucca Mountain, Southern Nevada: U.S. Geological Survey Bulletin 1790: Washington, D.C., 152 p.
Claassen, H.C., 1985, Sources and mechanisms of recharge for ground water in the west-central Amargosa Desert-A geochemical interpretation: U.S. Geological Survey Professional Paper 712-, 31 p.

Constantz, Jim, Stonestrom, D.A., Stewart, A.E., Niswonger, R.G., and Smith, T.R., 2001, Analysis of streambed temperatures in ephemeral channels to determine streamflow frequency and duration: Water Resources Research, v. 37, no. 2, p. 317-328.

Constantz, Jim, and Stonestrom, D.A., 2003, Heat as a tracer of water movement near streams, in Stonestrom, D.A., and Constantz, J., eds., Heat as a tool for studying the movement of ground water near streams: U.S. Geological Survey Circular 1260, p. 1-6.

Cook, P.G., Walker, G.R., and Jolly, I.D., 1989, Spatial variability of groundwater recharge in a semiarid region: Journal of Hydrology, v. 111, no. 1-4, p. 195-212.

Curtis, Scott, and Adler, R., 2000, ENSO indices based on patterns of satellite-derived precipitation: Journal of Climate, $\mathrm{v}$. 13 , no. 15 , p. 2786.

Dalrymple, Tate, and Benson, M.A., 1968, Measurement of peak discharge by the slope-area method: U.S. Geological Survey Techniques of Water-Resource Investigations, Book 3 Chapter A3, 12 p.

D’Agnese, F.A., Faunt, C.C., Hill, M.C., and Turner, A.K., 1999, Death Valley regional ground-water flow model calibration using optimal parameter estimation methods and geoscientific information systems: Advances in Water Resources, v. 22, no. 8, p. 777-790.

Eakin, T.E., and Maxey, G.B., 1951, Ground water in Ruby Valley, Elko and White Pine counties, Nevada, in Contributions to the hydrology of eastern Nevada: Nevada State Engineer's Office, Water Resources Bulletin, v. 12, p. 64-93.

Edmunds, W.M., Darling, W.G., and Kinniburgh, D.G., 1988, Solute profile techniques for recharge estimation in semiarid and arid terrain, in Summers, I., ed., Estimation of ntural goundwater rcharge: Norwell, Mass., D. Reidel, p. 139-157.

Fischer, J.M., 1992, Sediment properties and water movement through shallow unsaturated alluvium at an arid site for disposal of low-level radioactive waste near Beatty, Nye County, Nevada: U.S. Geological Survey Water-Resources Investigations Report 92-032, 63 p.

Gardner, W.H., 1986, Water content, in Klute, A., ed., Methods of soil analysis, part 1-Physical and mineralogical methods: Madison, Wisc., American Society of Agronomy, p. 493-544. 
Gee, G.W., Campbell, M.D., Campbell, G.S., and Campbell, J.H., 1992, Rapid measurement of low soil water potentials using a water activity meter: Soil Science Society of America Journal, v. 56, no. 4, p. 1068-1070.

Glazner, A.F., Walker, D., and Bartley, J., eds., 2002, Geologic evolution of the Mojave Desert and southwestern Basin and Range: Boulder, Colorado, Geological Society of America, 314 p.

Hamilton, W.B., 1987, Crustal extension in the Basin and Range Province, southwestern United States, in Coward, M.P., Dewey, J.F., and Hancock, P.L., eds., Continental extensional tectonics: Geological Society of America Special Publication 28, p. 155-176.

Harrill, J.R., Gates, J.S., and Thomas, J.M., 1988, Major ground-water flow systems in the Great Basin region of Nevada, Utah, and adjacent states: U.S. Geological Survey Hydrologic Investigations Atlas HA-694-C, scale 1:1,000,000.

Hartsough, Peter, Tyler, S.W., Sterling, J., and Walvoord, M.A., 2001, A $14.6 \mathrm{kyr}$ record of nitrogen flux from desert soil profiles as inferred from vadose zone pore waters: Geophysical Research Letters, v. 28, no. 15, p. 2955-2958.

Jarrett, R.D., 1987, Errors in slope-area computations of peak discharge in mountain streams: Journal of Hydrology, v. 96, no. $1-4$, p. 53-67.

Johnson, M.J., Mayers, C.J., and Andraski, B.J., 2002, Selected micrometeorological and soil-moisture data at Amargosa Desert Research Site in Nye County near Beatty, Nevada, 1998-2000: U.S. Geological Survey Open-File Report 02-348, 21 p.

Johnson, M.J., Mayers, C.J., Garcia, C.A., and Andraski, B.J., 2007, Selected micrometeorological, soil-moisture, and evapotranspiration data at Amargosa Desert Research Site in Nye County near Beatty, Nevada, 2001-2005: U.S. Geological Survey Digital Data Series 284, 52 p.

Kilroy, K.C., 1991, Ground-water conditions in the Amargosa Desert, Nevada-California, 1952-87: U.S. Geological Survey Water-Resources Investigations Report 89-4101, 91 p.

Laczniak, R.J., DeMeo, G.A., Reiner, S.R., Smith, J.L., and Nylund, W.E., 1999, Estimates of ground-water discharge as determined from measurements of evapotranspiration, Ash Meadows area, Nye County, Nevada: U.S. Geological Survey Water-Resources Investigations Report 99-4079, 70 p.

Maxey, G.B., and Eakin, T.E., 1949, Ground water in White River Valley, White Pine, Nye, and Lincoln Counties, Nevada, Nevada State Engineer's Office, Water Resources Bulletin, v. 8, 59 p.
Mayers, C.J., Andraski, B.J., Cooper, C.A., Wheatcraft, S.W., Stonestrom, D.A., and Michel, R.L., 2005, Modeling tritium transport through a deep unsaturated zone in an arid environment: Vadose Zone J., v. 4, no. 4, p. 967-976, doi:10.2136/vzj2004.0179.

McPhaden, M.J., Zebiak, S.E., and Glantz, M.H., 2006, ENSO as an integrating concept in Earth science: Science, v. 314, no. 5806, p. 1740-1745, doi:10.1126/science.1132588.

Moosburner, Otto, 1978, Flood investigations in Nevada through 1977 water year: U.S. Geological Survey Open-File Report 78-610, 94 p.

Nichols, W.D., 1987, Geohydrology of the unsaturated zone at the burial site for low-level radioactive waste near Beatty, Nye County, Nevada: U.S. Geological Survey Water-Supply Paper 2312, 57 p.

NOAA (National Oceanic and Atmospheric Administration), 2002, Monthly station normals of temperature, precipitation, and heating and cooling degree days, 1971-2000; 26, Nevada; Climatography of the United States No. 81: Ashville, National Climatic Data Center, 26 p.

Osterkamp, W.R., Lane, L.J., and Savard, C.S., 1994, Recharge estimates using a geomorphic/distributed-parameter simulation approach, Amargosa River Basin: Water Resources Bulletin, v. 30, no. 3, p. 493-507.

Page, A.L., Miller, R.H., and Keeney, D.R., eds., 1982, Methods of Soil Analysis, Part 2, Chemical and Microbiological Properties (2nd ed.): Madison, American Society of Agronomy, Inc., 1188 p.

Park, S.K., and Wernicke, B., 2003, Electrical conductivity images of Quaternary faults and Tertiary detachments in the California Basin and Range: Tectonics, v. 22, no. 4, p. 4-1 to 4-17, doi:10.1029/2001TC001324.

Philip, J.R., 1983, Infiltration in one, two, and three dimensions, in Slack, D.C., ed., Advances in infiltration: St. Joseph, Michigan, American Society of Agricultural Engineers, p. 1-13.

Phillips, F.M., 1994, Environmental tracers for water movement in desert soils of the American Southwest: Soil Science Society of America Journal, v. 58, no. 1, p. 15-24.

Prudic, D.E., Stonestrom, D.A., and Striegl, R.G., 1997, Tritium, deuterium, and oxygen-18 in water collected from unsaturated sediments near a low-level radioactive-waste burial site south of Beatty, Nevada: U.S. Geological Survey Water-Resources Investigations Report 97-4062, 23 p.

Scanlon, B.R., 2000, Uncertainties in estimating water fluxes and residence times using environmental tracers in an unsaturated zone: Water Resources Research, v. 36, no. 2, p. 395-409. 
Scanlon, B.R., Levitt, D.G., Reedy, R.C., Keese, K.E., and Sully, M.J., 2005, Ecological controls on water-cycle response to climate variability in deserts: Proceedings of the National Academy of Sciences of the United States of America, v. 102, no. 17, p. 6033-6038.

Smith, R.V., Doyle, R.M., Burns, L.C., and Stevens, R.J., 1997, A model for nitrite accumulation in soils: Soil Biology and Biochemistry, v. 29, no. 8, p. 1241-1247.

Smith, S.D., Monson, R.K., and Anderson, J.E., 1997, Physiological Ecology of North American Desert Plants: Berlin, Springer-Verlag, $286 \mathrm{p}$.

Spaulding, W.G., 1985, Vegetation and climates of the last 45,000 years in the vicinity of the Nevada Test Site, south-central Nevada: U.S. Geological Survey Professional Paper 1329, 83 p.

Spaulding, W.G., and Graumlich, L.J., 1986, The last pluvial climatic episodes in the deserts of southwestern North America: Nature, v. 320, p. 441-444.

Sparks, D.L., ed., 1996, Methods of Soil Analysis, Part 3, Chemical Methods: Madison, Wisc., American Society of Agronomy, $1390 \mathrm{p}$.

Stewart, A.E., 2003, Temperature based estimates of streamflow patterns and seepage losses in ephemeral channels: Stanford, Calif., Stanford University, Ph.D. dissertation, 248 p.

Stonestrom, D.A., Abraham, J.D., Lucius, J.E., and Prudic, D.E., 2003, Focused subsurface flow in the Amargosa Desert characterized by direct-current resistivity profiling [abs.]: Eos (American Geophysical Union Transactions), Fall Meeting Supplement, v. 84, no. 46, p. F660.

Stonestrom, D.A., and Blasch, K.W., 2003, Determining temperature and thermal properties for heat-based studies of surface-water ground-water interactions, in Stonestrom, D.A., and Constantz, J., eds., Heat as a tool for studying the movement of ground water near streams: U.S. Geological Survey Circular 1260, p. 73-80.

Stonestrom, D.A., Prudic, D.E., Laczniak, R.J., Akstin, K.C., Boyd, R.A., and Henkelman, K.K., 2003, Estimates of deep percolation beneath irrigated fields, native vegetation, and the Amargosa River channel, Amargosa Desert, Nye County, Nevada: U.S. Geological Survey Open-File Report 03-104, 83 p.

Stonestrom, D.A., Prudic, D.E., Laczniak, R.J., and Akstin, K.C., 2004, Tectonic, climatic, and land-use controls on ground-water recharge in an arid alluvial basin: Amargosa Desert, U.S.A., in Hogan, J.F., Phillips, F.M., and Scanlon, B.R., eds., Groundwater recharge in a desert environmentThe southwestern United States: American Geophysical Union, Water Science and Applications Series, v. 9, p. 29-47, doi:10.1029/0009WSA03.
Stonestrom, D.A., Prudic, D.E., and Striegl, R.G., 1999, Isotopic composition of water in a deep unsaturated zone beside a radioactive-waste disposal area near Beatty, Nevada, in Morganwalp, D.W., and Buxton, H.T., eds., U.S. Geological Survey Toxic Substances Hydrology Program-Proceedings of the Technical Meeting, Charleston, South Carolina, March 8-12, 1999-Volume 3-Subsurface Contamination from Point Sources: U.S. Geological Survey Water Resources Investigations Report 99-4018C, p. 467-473.

Sweetkind, D.S., Dickerson, R.P., Blakely, R.J., and Denning, P.D., 2001, Interpretive Geologic Cross Sections for the Death Valley Regional Flow System and Surrounding Areas, Nevada and California: U.S. Geological Survey Miscellaneous Field Studies Map MF-2370, scale 1:750,000.

Szabo, B.J., Kolesar, P.T., Riggs, A.C., Winograd, I.J., and Ludwig, K.R., 1994, Paleoclimatic inferences from a 120,000-yr old calcite record of water-table fluctuation in Browns Room of Devils Hole, Nevada: Quaternary Research, v. 41, p. 59-69.

Tanko, D.J., and Glancy, P.A., 1999, Flooding in the Amargosa River Basin, February 23-24, southern Nevada and eastern California, including the Nevada Test Site: U.S. Geological Survey Fact Sheet FS-036-01, 4 p.

Telford, W.M., Geldart, L.P., and Sheriff, R.E., 1990, Applied geophysics (2nd ed.): New York, Cambridge University Press, $770 \mathrm{p}$.

Tiedeman, C.R., D. M. Ely, M. C. Hill, and G. M. O'Brien, 2004, A method for evaluating the importance of system state observations to model predictions, with application to the Death Valley regional groundwater flow system: Water Resources Research., v. 40, no. 12, p. 1-14, doi:10.1029/2004WR003313.

Tyler, S.W., Chapman, J.B., Conrad, S.H., Hammermeister, D.P., Blout, D.O., Miller, J.J., Sully, M.J., and Ginanni, J.M., 1996, Soil-water flux in the southern Great Basin, United States-Temporal and spatial variations over the last 120,000 years: Water Resources Research, v. 32, no. 6, p. 1481-1499.

U.S. Census Bureau, 2003, Nevada 2000 Summary Social, Economic, and Housing Characteristics, 2000 Census of Population and Housing, Publication PHC-2-30: Washington, D.C., 162 p.

Vecchi, G.A., Wittenberg, A.T., and Rosati, A., 2006, Reassessing the role of stochastic forcing in the 1997-1998 El Niño: Geophysical Research Letters, v. 33, doi:10.1029/2005GL024738. 
Walker, G.E., and Eakin, T.E., 1963, Geology and ground water of Amargosa Desert, Nevada-California: Nevada Department of Conservation and Natural Resources, Ground-Water Resources Reconnaissance Series Report $14,45 \mathrm{p}$.

Walvoord, M.A., Phillips, F.M., Tyler, S.W., and Hartsough, P.C., 2002, Deep arid system hydrodynamics 2. Application to paleohydrologic reconstruction using vadose zone profiles from the northern Mojave Desert: Water Resources Research, v. 38 , no. 12 , p. $27-1$ to $27-12$.

Walvoord, M.A., Plummer, M.A., Phillips, F.M., and Wolfsberg, A.V., 2002, Deep arid system hydrodynamics 1. Equilibrium states and response times in thick desert vadose zones: Water Resources Research, v. 38, no. 12, p. 44-1 to 44-15, doi:10.1029/2001WR000824.
Walvoord, M.A., Stonestrom, D.A., Andraski, B.J., and Striegl, R.G., 2004, Constraining the inferred paleohydrologic evolution of a deep unsaturated zone in the Amargosa Desert: Vadose Zone Journal, v. 3, no. 2, p. 502-512.

Winograd, I.J., and Thordarson, W., 1975, Hydrogeologic and hydrochemical framework, South-Central Great Basin, Nevada-California, with special reference to the Nevada Test Site: U.S. Geological Survey Professional Paper 712-C, 126 p.

Workman, J.B., Menges, C.M., Page, W.R., Taylor, E.M., Ekren, E.B., Rowley, P.D., Dixon, G.L., Thompson, R.A., and Wright, L.A., 2002, Geologic map of the Death Valley ground-water model area, Nevada and California: U.S. Geological Survey Miscellaneous Field Studies Map MF2381-A, 46 p., 2 sheets. 